\title{
Cloning, expression and characterization of a chitinase from Paenibacillus chitinolyticus strain UMBR 0002
}

\author{
Cong Liu ${ }^{1}$, Naikun Shen ${ }^{2}$, Jiafa Wu ${ }^{2}$, Mingguo Jiang ${ }^{\text {Corresp., }}{ }^{2}$, Songbiao Shi ${ }^{1}$, Jinzi Wang ${ }^{2}$, Yanye Wei ${ }^{2}$, Lifang Yang \\ Corresp. 1 \\ ${ }^{1}$ Guangxi Key Laboratory of Chemistry and Engineering of Forest Products, Guangxi Key Laboratory for Polysaccharide Materials and Modifications, School \\ of Chemistry and Chemical Engineering, Guangxi University for Nationalities, Nanning, China \\ 2 School of Marine Sciences and Biotechnology, Guangxi University for Nationalities, Nanning, China \\ Corresponding Authors: Mingguo Jiang, Lifang Yang \\ Email address: mzxyjiang@gxun.edu.cn, yanglf1990@gxun.edu.cn
}

Background. Chitinases are enzymes which degrade $\beta-1,4-$ glycosidid linkages in chitin. The enzymatic degradation of shellfish waste ( containing chitin ) to chitooligosaccharides is used in industrial applications to generate high-value-added products from such waste. However, chitinases are currently produced with low efficiency and poor tolerance, limiting the industrial utility. Therefore, identifying chitinases with higher enzymatic activity and tolerance is of great importance. Methods. Primers were designed using the genomic database of Paenibacillus chitinolyticus NBRC 15660. An exochitinase (CHI) was cloned into the recombinant plasmid pET-22b (+) to form pET-22b (+)-CHI, which was transformed into Escherichia coli TOP10 to construct a genomic library. Transformation was confirmed by colony-polymerase chain reaction and electrophoresis. The target sequence was verified by sequencing. Recombinant $\mathrm{pET}-22 \mathrm{~b}(+)-\mathrm{CHI}$ was transformed into $E$. coli Rosetta-gami B(DE3) for expression of chitinase. Recombinant protein was purified by NiNTA affinity chromatography, and enzymatic analysis was carried out. Results. The exochitinase $\mathrm{CHI}$ from $P$. chitinolyticus strain UMBR 0002 was successfully cloned and heterologously expressed in E. coli Rosetta-gami B (DE3). Purification yielded a 13.36-fold enrichment and recovery yield of $72.2 \%$. The purified enzyme had a specific activity of $750.64 \mathrm{mU} \mathrm{mg}^{-1}$. The optimum $\mathrm{pH}$ and temperature for degradation of colloidal chitin were 5.0 and $45{ }^{\circ} \mathrm{C}$, respectively. The enzyme showed high stability, retaining $>70 \%$ activity at $\mathrm{pH} 4.0-10.0$ and $25-45^{\circ} \mathrm{C}$ (maximum of $90 \mathrm{~min}$ ). The activity of $\mathrm{CHI}$ strongly increased with the addition of $\mathrm{Ca}^{2+}, \mathrm{Mn}^{2+}$, Tween 80, and urea. Conversely, $\mathrm{Cu}^{2+}, \mathrm{Fe}^{3+}$, acetic acid, isoamyl alcohol, sodium dodecyl sulfate, and $\beta$-mercaptoethanol significantly inhibited enzyme activity. The oligosaccharides produced by $\mathrm{CHI}$ from colloidal chitin exhibited a degree of polymerization, forming $\mathrm{N}$-acetylglucosamine (GICNAc) and (GlcNAc) ${ }_{2}$ as products. Conclusions. This is the first report of the cloning, heterologous expression and 
purification of a chitinase from $P$. chitinolyticus strain UMBR 0002. The results highlight $\mathrm{CHI}$ as a good candidate enzyme for green degradation of chitinous waste. 


\section{Cloning, expression and characterization of a chitinase from}

\section{Paenibacillus chitinolyticus strain UMBR 0002}

3 Cong $\mathrm{Liu}^{1}$, Naikun Shen ${ }^{2}$,Jiafa $\mathrm{Wu}^{2}$, Mingguo Jiang ${ }^{2, *}$, Songbiao Shi ${ }^{1}$,

4 Jinzi Wang ${ }^{2}$, Yanye $\mathrm{Wei}^{2}$, Lifang Yang ${ }^{1, *}$

$5 \quad{ }^{1}$ Guangxi Key Laboratory of Chemistry and Engineering of Forest Products, Guangxi Key

6 Laboratory for Polysaccharide Materials and Modifications, School of Chemistry and Chemical

7 Engineering, Guangxi University for Nationalities, Nanning, China

$8{ }^{2}$ School of Marine Sciences and Biotechnology, Guangxi University for Nationalities, Nanning,

9 China

$10 *$ *orresponding author: Mingguo Jiang, E-mail: mzxyjiang@gxun.edu.cn; Lifang Yang, E-mail:

11 yanglf1990@gxun.edu.cn.

\section{Abstract}

13 Background. Chitinases are enzymes which degrade $\beta-1,4$-glycosidid linkages in chitin. The enzymatic degradation of shellfish waste (containing chitin) to chitooligosaccharides is used in

15 industrial applications to generate high-value-added products from such waste. However,

16 chitinases are currently produced with low efficiency and poor tolerance, limiting the industrial

17 utility. Therefore, identifying chitinases with higher enzymatic activity and tolerance is of great importance. 
19 Methods. Primers were designed using the genomic database of Paenibacillus chitinolyticus

20 NBRC 15660. An exochitinase (CHI) was cloned into the recombinant plasmid pET-22b $(+)$ to

21 form $\mathrm{pET}-22 \mathrm{~b}(+)-\mathrm{CHI}$, which was transformed into Escherichia coli TOP10 to construct a

22 genomic library. Transformation was confirmed by colony-polymerase chain reaction and

23 electrophoresis. The target sequence was verified by sequencing. Recombinant $\mathrm{pET}-22 \mathrm{~b}(+)-\mathrm{CHI}$

24 was transformed into $E$. coli Rosetta-gami $\mathrm{B}(\mathrm{DE} 3)$ for expression of chitinase. Recombinant

25 protein was purified by Ni-NTA affinity chromatography, and enzymatic analysis was carried

26 out.

27 Results. The exochitinase CHI from $P$. chitinolyticus strain UMBR 0002 was successfully

28 cloned and heterologously expressed in E. coli Rosetta-gami B (DE3). Purification yielded a

29 13.36-fold enrichment and recovery yield of $72.2 \%$. The purified enzyme had a specific activity

30 of $750.64 \mathrm{mU} \mathrm{mg}^{-1}$. The optimum $\mathrm{pH}$ and temperature for degradation of colloidal chitin were

315.0 and $45{ }^{\circ} \mathrm{C}$, respectively. The enzyme showed high stability, retaining $>70 \%$ activity at $\mathrm{pH}$

$324.0-10.0$ and $25-45^{\circ} \mathrm{C}$ (maximum of $90 \mathrm{~min}$ ). The activity of $\mathrm{CHI}$ strongly increased with the

33 addition of $\mathrm{Ca}^{2+}, \mathrm{Mn}^{2+}$, Tween 80 , and urea. Conversely, $\mathrm{Cu}^{2+}, \mathrm{Fe}^{3+}$, acetic acid, isoamyl alcohol,

34 sodium dodecyl sulfate, and $\beta$-mercaptoethanol significantly inhibited enzyme activity. The

35 oligosaccharides produced by $\mathrm{CHI}$ from colloidal chitin exhibited a degree of polymerization,

36 forming $\mathrm{N}$-acetylglucosamine (GlcNAc) and $(\mathrm{GlcNAc})_{2}$ as products. 
37 Conclusions. This is the first report of the cloning, heterologous expression and purification of a

38 chitinase from $P$. chitinolyticus strain UMBR 0002. The results highlight CHI as a good

39 candidate enzyme for green degradation of chitinous waste.

\section{Introduction}

42 Chitin is composed of linear chains of poly- $\beta-1,4-\mathrm{N}$-acetylglucosamine, and is found in the

43 exoskeletons of arthropods and fungal cell walls. Chitin is the second most abundant and

44 renewable natural polysaccharide after cellulose (Li et al., 2010; Yang et al., 2009; Karthik,

45 Binod \& Pandey, 2015), and forms the structural components of the cells of numerous organisms

46 (Rameshthangam et al., 2018). However, chitin waste does not degrade readily; an attractive

47 solution would be to extract chitin and its derivatives from chitin-rich waste and convert the

48 waste into high-value-added products (Nawani et al., 2002). The degradation products of chitin

49 have many properties including antifungal activity, biocompatibility, biodegradability, non-

50 toxicity, and adsorption, meaning that they have utility in many fields, such as materials and

51 medical sciences, food and nutrition, biotechnology, agriculture, and environmental protection

52 (Guo et al., 2019; Hamed, Özogul \& Regenstein, 2016; Meena et al., 2014). Chitinases (EC

53 3.2.2.14) catalyze the degradation of chitin by cleaving the $\beta-1,4$ linkages of N-

54 acetylglucosamine units (Salas-Ovilla et al., 2019). Bioprocesses for recycling and degrading

55 waste chitin using chitinase have been adopted for the industrial production of GlcNAc (Das et 
56 al., 2019). At present, degradation products of chitin are usually generated through chemical

57 degradation, which not only has high energy consumption but also creates serious environmental

58 pollution. However, degradation of chitin by chitinases is controllable and low cost, and can

59 produce high yields in mild conditions with minimal environmental impacts (Deng et al., 2019;

60 Kidibule et al., 2018; Salas-Ovilla et al., 2019). In nature, more than $10^{9}$ tons of chitin is

61 produced each year (Menghiu et al., 2019), and over 10,000 tons of shellfish waste is produced

62 annually, most of which is thrown into the sea or land fill. If this waste is not fully decomposed,

63 it may have negative effects on the environment and human health (Rameshthangam et al., 2018;

64 Wang et al., 2018). Reducing the large amount of waste and creating high-value-added products

65 from chitin waste is of high importance.

66 Chitinases can be subdivided into three families based on their structural motives: the glycoside

67 hydrolase families 18, 19, and 20 (Take et al., 2018). Chitinases can be further classified as

68 endochitinases, exochitinases, or N-acetylglucosaminases (NAGases) based on the mechanism of

69 chitin hydrolysis. Endochitinases (EC 3.2.1.14) randomly cleave chitin at internal sites to

70 produce soluble, low-molecular-mass GlcNAc oligomers. Exo-chitinases can be subdivided into

71 chitobiosidases (EC 3.2.1.29) and 1-4- $\beta$-glucosaminidases (EC 3.2.1.30). The former releases

72 (GlcNAc $)_{2}$ from the non-reducing end of chitin chains. The latter acts on $\beta$-1, 4-glycosidic bonds

73 at the end of chain of low-molecular-mass GlcNAc oligomers and chitobiosidases to generate

74 GlcNAc monomers (Hamid et al., 2013; Zhou et al., 2019). Bacterial chitinase offers wide

75 environmental adaptability, fast expression, high thermal stability; furthermore, the enzyme can 
76 be genetically engineered (Le \& Yang, 2019). Chitinase-producing bacteria have been isolated

77 from many sources such as soil, shellfish waste, compost, and hot springs (Hamid et al., 2013).

78 Many bacteria can produce chitinases, including Streptomyces, Pseudomonas, Sanguibacter,

79 Paenibacillus, Serratia, Fusarium, Clostridium, Flavobacterium, Alteromonas, Bacillus,

80 Microbispora, Chromobacterium, Erwinia, and Vibrio (Bouacem et al., 2018; Das et al., 2019;

81 Nawani et al., 2002; Stoykov, Pavlov \& Krastanov, 2015; Vaikuntapu et al., 2016). Many of

82 these produce chitinases which work at moderate temperature or neutral conditions (Bouacem et

83 al., 2018). However, chitinases are usually tolerant to, for example, extremes of $\mathrm{pH}$ and

84 temperature for long periods, making them suitable for use in practical industrial applications

85 (Karthik, Binod \& Pandey, 2015). Compared with those derived from terrestrial organisms,

86 marine chitinases usually exhibit higher tolerance of $\mathrm{pH}$ and salinity (Das et al., 2019; Han et

87 al., 2009). Therefore, it is important to screen for highly tolerant, novel marine chitinases.

88 In our previous study, we isolated a marine bacterium capable of producing chitinase from a

89 sample of shrimp-pond bottom mud from mangroves in the Maowei Sea in China, which we

90 identified to be Paenibacillus chitinolyticus strain UMBR 0002. The majority of previous studies

91 on P. chitinolyticus have focused on the wild bacterium (Song et al., 2012; Mihajlovski et al.,

92 2017). As far as I known, few studies have been reported that chitinase genes from $P$.

93 chitinolyticus have been cloned. In the present study, we report the cloning, heterologous

94 expression, and purification of a chitinase (CHI) from P. chitinolyticus strain UMBR 0002 for 
95 the first time. The enzymatic properties and products were analyzed to provide a theoretical basis

96 for effective utilization of this enzyme for the degradation of chitin waste.

\section{Methods}

\section{Materials}

99 We obtained DNA polymerases, Bam HI and $\mathrm{XhoI}$ restriction endonucleases, and $\mathrm{T}_{4}$ ligase from

100 TaKaRa (Dalian, China). The TIANamp Bacteria DNA Kit, TIANprep Mini Plasmid Kit, and

101 Universal DNA Purification Kit were all purchased from Tiangen Biotech CO., Ltd. (Beijing,

102 China). EasyPure Quick Gel Extraction Kit was purchased from TransGen Biotech CO., Ltd.

103 (Beijing, China). His-Tagged Protein Purification Kit (Soluble Protein) was obtained from

104 ComWin Biotech Co., Ltd. (Beijing, China). Host cell strains, E. coli TOP10 and Rosetta-gami B

105 (DE3), were obtained from TransGen Biotech CO., Ltd. and Sangon Biotech Co., Ltd.

106 (Shanghai, China), and the pET-22b (+) was purchased from Sangon Biotech Co., Ltd. Chitin

107 powder (from crab shells), chitosan oligosaccharide (degree of deacetylation [DDA] $>90 \%$ ),

108 carboxymethyl cellulose sodium salt $(\mathrm{CMC}-\mathrm{Na})$, and carboxymethyl chitosan (DDA $\geq 90 \%$ ) were

109 obtained from Solarbio (Beijing, China), Dalian Zhongke Glake Biotechnology Co., Ltd.

110 (Dalian, China), Damao Chemical Reagent Factory (Tianjin, China ) and Hefei Bomei

111 Biotechnology Co., Ltd. (Hefei, China), respectively. All other chemicals used in this study were

112 of analytical grade. The P. chitinolyticus strain UMBR 0002 was reserved in the Guangdong

113 culture collection center under the number GDMCC 60710. 


\section{Strains and culture conditions}

115 Paenibacillus chitinolyticus strain UMBR 0002 was grown in sterile chitin medium at pH 7.0

116 containing (in $\mathrm{g} \mathrm{L}^{-1}$ ): colloidal chitin 3.0, tryptone 5.0, inorganic salt mixture 10.0, and agar

117 powder 15.0 (for solid culture medium). The inorganic salt mixture contained (in $\mathrm{g} \mathrm{L}^{-1}$ ): $\mathrm{KNO}_{3}$

$118100.0, \mathrm{~K}_{2} \mathrm{HPO}_{4} 50.0, \mathrm{NH}_{4} \mathrm{NO}_{3}$ 10.0, $\mathrm{MgSO}_{4} \cdot 7 \mathrm{H}_{2} \mathrm{O} 50.0, \mathrm{NaCl} 50.0, \mathrm{FeSO}_{4} 1.0, \mathrm{MnCl}_{2} \cdot \mathrm{H}_{2} \mathrm{O} 0.1$, 119 and $\mathrm{ZnSO}_{4} \cdot 7 \mathrm{H}_{2} \mathrm{O} 0.1$.

120 The E. coli TOP10 and Rosetta-gami B (DE3) strains were cultivated in sterile Luria-Bertani

121 (LB) medium at $\mathrm{pH} 7.4 \pm 0.2$, containing (in $\mathrm{g} \mathrm{L}^{-1}$ ): tryptone 10.0, yeast extract 5.0, $\mathrm{NaCl} 10.0$,

122 and agar powder 15.0 (for solid culture medium).

\section{Preparation of colloidal chitin}

124 Colloidal chitin was prepared according to the method of Laribi-Habchi (Laribi-Habchi et al.,

125 2015) with minor modifications. Briefly, $10.0 \mathrm{~g}$ of chitin powder dissolved in $176 \mathrm{~mL}$ of

126 concentrated hydrochloric acid (12 M), stirred well and stored at $4^{\circ} \mathrm{C}$ for $24 \mathrm{~h}$. Thereafter, $1.0 \mathrm{~L}$

127 of distilled water was added to the chitin solution and the mixture incubated for another $24 \mathrm{~h}$ at 4

$128{ }^{\circ} \mathrm{C}$. The precipitate was harvested by centrifugation at 8,000 rpm for $10 \mathrm{~min}$ and washed

129 repeatedly with sterile distilled water until the $\mathrm{pH}$ reached 7.0. Finally, the precipitate was

130 dissolved in sterile distilled water to a final concentration of $25.0 \mathrm{~g} \mathrm{~L}^{-1}$. The solution was stored

131 at $4^{\circ} \mathrm{C}$ for subsequent use. 


\section{Activity assay}

133 The specific activity ( $\mathrm{mU} \mathrm{mg}^{-1}$ protein) of purified recombinant $\mathrm{CHI}$ and crude protein extracts

134 solution toward colloidal chitin were determined according to the method described by Miller

135 (Miller GL,1959). Diluted recombinant protein solution $(100 \mu \mathrm{L})$ in phosphate buffer was mixed

136 with colloidal chitin (at a final concentration of $0.5 \%$ ), and incubated for $1 \mathrm{~h}$ at $45^{\circ} \mathrm{C}$ along with

137 appropriate blanks. The reaction was stopped by the addition of $300 \mu \mathrm{L}$ 3,5-dinitrosalicylic acid

138 (DNS) followed by heating for $10 \mathrm{~min}$ in a boiling water bath. After the reaction system was

139 cooled to room temperature, $300 \mu \mathrm{L}$ of deionized water was added to the mixture, and the

140 resulting solution was centrifuged at 8,000 rpm for $10 \mathrm{~min}$. The optical density (OD) of the

141 supernatant was measured at $540 \mathrm{~nm}$ using a BioTek spectrophotometer (Epoch, USA).

142 Chitinase activity was determined by colorimetry, based on the amount of GlcNAc released from

143 colloidal chitin. This was calculated by comparing $\mathrm{OD}_{540}$ data with a standard curve prepared

144 from serial dilutions of GlcNAc (from 0.1 to $1 \mathrm{mg} \mathrm{mL}^{-1}$ ) (Mohamed et al., 2019). One unit of

145 chitinase activity was defined as the amount of enzyme that releases $1 \mu \mathrm{moL}$ of GlcNAc from

146 colloidal chitin per min under the specified assay conditions.

\section{Plasmids and cloning of the chitinase gene}

148 Oligonucleotide primers used for the cloning of the chitinase (CHI) gene from P. chitinolyticus

149 strain UMBR 0002 were designed from the genomic database of $P$. chitinolyticus NBRC 15660

150 (GenBank accession number NZ_BBJT00000000.1). The nucleotide sequence of CHI gene was 
151 deposited in GenBank with the accession number MN121846

152 (https://www.ncbi.nlm.nih.gov/nuccore/MN121846). A DNA extraction kit was used to obtain

153 DNA, which was then used as the template for polymerase chain reaction (PCR) amplification.

154 The gene encoding CHI was amplified using $P f u$ DNA polymerase and the following primer

155 pairs: 5'-GGATCCCGAACCGGCCAAAATCGTCGG-3' and 5'-

156 CTCGAGGCTGCCTGTTACCACAATATTCG-3' (underlining indicates the added BamHI and

157 XhoI sites). The PCR program was as follows: initial denaturation at $98^{\circ} \mathrm{C}$ for 8 min, followed

158 by 30 cycles of $98{ }^{\circ} \mathrm{C}$ for $30 \mathrm{~s}, 55^{\circ} \mathrm{C}$ for $45 \mathrm{~s}$, and $72{ }^{\circ} \mathrm{C}$ for $2 \min 30 \mathrm{~s}$, with a final extension

159 step at $72{ }^{\circ} \mathrm{C}$ for $10 \mathrm{~min}$. The PCR samples were purified using a Universal DNA Purification

160 Kit, digested with BamHI and XhoI, and then ligated into a BamHI- and XhoI-digested vector

$161 \mathrm{pET}-22 \mathrm{~b}(+)$ to generate $\mathrm{pET}-22 \mathrm{~b}(+)-\mathrm{CHI}$. The recombinant plasmid was transformed into $E$.

162 coli TOP10 and verified using automated DNA sequencing (Sangon).

\section{Bioinformatic analyses}

164 The open reading frame (ORF) and encoded amino acid sequence of CHI were analyzed using

165 ORF Finder (https://www.ncbi.nlm.nih.gov/orffinder/) followed by translation of the nucleotide

166 sequence using DNAMAN software. Domain structure was analyzed at the National Center for

167 Biotechnology Information (NCBI) (https://blast.ncbi.nlm.nih.gov/Blast.cgi) and the three-

168 dimensional (3D) structure of CHI was predicted using SWISS-MODEL

169 (https://swissmodel.expasy.org/) (Jiang et al., 2017). A phylogenetic neighbor-joining tree was 
170 constructed using MEGA 5.0 software, and ClustalW was used for sequence alignment (Liu et

171 al., 2018; Noby et al., 2018).

172 Expression and purification of chitinase

173 For the expression of recombinant CHI, pET-22b (+)-CHI was transformed into E. coli Rosetta-

174 gami B (DE3) cells. Cells were cultured at $37{ }^{\circ} \mathrm{C}$ in liquid LB medium containing $100 \mu \mathrm{g} \mathrm{mL}{ }^{-1}$

175 ampicillin. Expression was induced by the addition of $0.5 \mathrm{mM}$ isopropyl thio- $\beta$-D-galactoside

176 (IPTG) when the $\mathrm{OD}_{600}$ reached 0.6-1.0, after which cells were incubated at $37{ }^{\circ} \mathrm{C}$ for a further 8

177 h. Protein expression was checked by sodium dodecyl sulfate polyacrylamide gel electrophoresis

178 (SDS-PAGE) (10\% separation gel, $4 \%$ concentrated gel). The cell pellet was collected by

179 centrifugation at $8,000 \mathrm{rpm}$ for $10 \mathrm{~min}$ and stored at $4{ }^{\circ} \mathrm{C}$. The freshly-prepared cell pellet was

180 resuspended in lysis buffer $(0.1 \mathrm{M}$ Tris- $\mathrm{HCl}, \mathrm{pH} 8.1$, containing $0.3 \mathrm{M} \mathrm{NaCl})$, then lysed on ice

181 using an ultrasonic cell disrupter (JY92-IIN, Ningbo Scientz Biotechnology Co.,LTD.) followed

182 by centrifugation $\left(8000 \mathrm{rpm}, 15 \mathrm{~min}, 4^{\circ} \mathrm{C}\right)$ to remove cell debris and unbroken cells. The

183 supernatant, comprising crude protein extracts containing CHI, was immediately applied to a 5-

184 mL Ni-NTA affinity chromatography column pre-equilibrated with binding buffer (0.1 M Tris-

$185 \mathrm{HCl}, \mathrm{pH} 8.1,0.3 \mathrm{M} \mathrm{NaCl}$ and $10 \mathrm{mM}$ imidazole) at $4{ }^{\circ} \mathrm{C}$. The column was washed with $50 \mathrm{~mL}$ of

186 wash buffers $(0.1 \mathrm{M}$ Tris- $\mathrm{HCl}, \mathrm{pH} 8.1,0.3 \mathrm{M} \mathrm{NaCl}$ and $20 \mathrm{mM}$ imidazole, then $0.1 \mathrm{M}$ Tris-HCl,

$187 \mathrm{pH} 8.1,0.3 \mathrm{M} \mathrm{NaCl}$ and $60 \mathrm{mM}$ imidazole). Chitinase was eluted with $40 \mathrm{~mL}$ buffer containing

188 0.1 M Tris-HCl ( $\mathrm{pH} 8.1$ ), 0.3 M NaCl, and $150 \mathrm{mM}$ and $250 \mathrm{mM}$ imidazole, respectively. Purity 
189 of the recombinant protein was analyzed using 10\% SDS-PAGE with Coomassie Brilliant Blue

190 R-250 staining. The molecular mass of the purified enzyme was determined by comparison with

191 protein molecular weight markers (Product \#: 26616, Thermo Scientific, Beijing, China). The

192 eluted fractions which contained target protein were concentrated and exchanged into a $50 \mathrm{mM}$

193 phosphate buffer, pH 7.0, using 30-kDa centrifugal filter units (Millipore, Beijing, China).

194 Protein concentrations were determined using the Bradford method (Bradford, 1976), and

195 enzyme preparations were stored at $4{ }^{\circ} \mathrm{C}$ until use.

\section{Biochemical characterization of chitinase}

197 The optimum temperature for CHI activity was determined by incubating enzyme preparations

198 with colloidal chitin at various temperatures between $25-80^{\circ} \mathrm{C}$ in $50 \mathrm{mM}$ phosphate buffer at $\mathrm{pH}$

199 7.0. Thermostability was tested by preincubating the enzyme at various temperatures from 25 to

$20070^{\circ} \mathrm{C}$ without substrate for 60 or $90 \mathrm{~min}$. The optimum $\mathrm{pH}$ was determined by carrying out the

201 reaction at $\mathrm{pH}$ 2.0-11.0 with $0.2 \mathrm{M}$ phosphate $(\mathrm{pH} 2.0-8.0)$ or $0.2 \mathrm{M}$ glycine- $\mathrm{NaOH}(\mathrm{pH}$ 8.0-

202 11.0) buffers. Chitinase was preincubated at $\mathrm{pH} 2.0-11.0$ in the appropriate buffer at $4{ }^{\circ} \mathrm{C}$ for $5 \mathrm{~h}$

203 prior to the activity assay. The residual enzyme activity was tested at the optimum $\mathrm{pH}$. The

204 effects of metal ions and chemical reagents $\left(\mathrm{Ca}^{2+}, \mathrm{Mg}^{2+}, \mathrm{Zn}^{2+}, \mathrm{Na}^{+}, \mathrm{K}^{+}, \mathrm{Al}^{3+}, \mathrm{NH}_{4}^{+}, \mathrm{Co}^{2+}, \mathrm{Ba}^{2+}\right.$,

$205 \mathrm{Cu}^{2+}, \mathrm{Fe}^{3+}, \mathrm{Mn}^{+}, \mathrm{Ag}^{+}, \mathrm{Cd}^{2+}$, Tris, sodium dodecyl sulfate [SDS], ethylenediaminetetraacetic acid

206 [EDTA], and urea) on CHI activity at final concentrations of 10 and $50 \mathrm{mM}$ were also

207 investigated, as were the effects of organic solvents and reagents (methanol, ethanol, 
208 isopropanol, glycerin, isoamyl alcohol, Tween 80, acetic acid, chloroform, dimethylsulfoxide

209 [DMSO], and $\beta$-mercaptoethanol) at final concentrations of $10 \%$ and $20 \%(\mathrm{v} / \mathrm{v})$. The effect of

$210 \mathrm{NaCl}$ on $\mathrm{CHI}$ activity was determined by incubating the enzyme with $\mathrm{NaCl}$ at final

211 concentrations of $0.5 \%, 1.5 \%, 3 \%, 4.5 \%, 6 \%, 7.5 \%, 9 \%$, or $12.5 \%$ at $4{ }^{\circ} \mathrm{C}$ for $1 \mathrm{~h}$. Residual CHI

212 activity was measured in standard assay conditions. Appropriate controls were used.

\section{Substrate specificity}

214 The specificity of recombinant CHI was tested toward various substrates such as colloidal chitin,

215 chitin powder, chitosan oligosaccharide, carboxymethyl cellulose sodium salt (CMC-Na), and

216 carboxymethyl chitosan by adding the compounds to the assay mixture individually at a final

217 concentration of $0.5 \%(\mathrm{w} / \mathrm{v})$. Relative enzyme activity was then determined in standard

218 conditions with the highest activity being taken as $100 \%$.

\section{Product analysis}

220 The major products of colloidal chitin hydrolysis by CHI was identified using electrospray

221 ionization-mass spectrometry (ESI-MS; AB Sciex, USA) analysis. The reaction mixture

222 containing $100 \mu \mathrm{L}$ colloidal chitin (1\%) and $0.25 \mathrm{mg} \mathrm{CHI}$ in $50 \mathrm{mM} 100 \mu \mathrm{L}$ phosphate buffer

223 (pH 7.0) was incubated at $45^{\circ} \mathrm{C}$ for $0.5 \mathrm{~h}, 1 \mathrm{~h}, 6 \mathrm{~h}$, and $14 \mathrm{~h}$. After incubation, the reaction

224 mixture was boiled for $5 \mathrm{~min}$ and centrifuged at $8,000 \mathrm{rpm}$ for $10 \mathrm{~min}$ at $4{ }^{\circ} \mathrm{C}$. The supernatant

225 was analyzed by ESI-MS. 


\section{Results}

\section{Expression and purification of chitinase}

228 The gene encoding chitinase was successfully isolated from P. chitinolyticus strain UMBR 0002,

229 and recombinant CHI was heterologously expressed in E. coli Rosetta-gami B (DE3) and

230 purified. The molecular weight was estimated to be between 70 and $100 \mathrm{kDa}$ by SDS-PAGE

231 (Fig. 1), which is consistent with the expected weight of approximately $80 \mathrm{kDa}$ according to the

232 translated nucleotide sequence. In our study, recombinant CHI was purified with 13.36-fold

233 enrichment and a recovery yield of $72.2 \%$. The purified enzyme had a specific activity of 750.64

$234 \mathrm{mU} \mathrm{mg}^{-1}$ (Table 1).

\section{Bioinformatic analysis}

236 The gene encoding CHI included a complete ORF encoding a protein of 765 amino acids.

237 Domain structure analysis revealed CHI to contain a chitin-binding domain (CBD) and two

238 fibronectin-type-III domains (FN3). The enzyme was identified to belong to glycoside hydrolase

239 family 18 (Fig. 2A). Sequence alignment using BLASTP software (NCBI) revealed that CHI

240 exhibits $98.26 \%$ sequence identity and 97\% sequence coverage with chitinase from $P$.

241 chitinolyticus (WP_042235807.1), followed by chitinase Chi80 from P. ehimensis

242 (BAC76694.1) (97.58\% identity and 97\% sequence coverage), chitinase from Paenibacillus

243 sp.UNC499MF (WP_103996460.1) (95.49\% identity and 95\% sequence coverage), chitinase

244 from Paenibacillus sp. FJAT-26967 (WP_068776920.1) (79.59\% identity and 94\% sequence 
245 coverage), and chitinase from Bacillus sp. EAC (WP_088042647.1) (62.62\% identity and 94\%

246 sequence coverage). Multiple sequence alignment showed that, although the coding amino acid

247 sequences of different chitinases vary greatly, the key amino acids within the catalytic domain

248 are highly conserved. In this study, two conserved motifs with the sequences KxxxxxGGW and

249 FDGxDLDWEYP were identified in CHI (Fig. 2B). Within these conserved sequences, CHI has

250 two conserved modules typical of the glycoside hydrolase family 18, SxGG and DxxDxDxE,

251 which are responsible for substrate binding and catalytic degradation, respectively. Glutamic

252 acid (E) represents a general acid/base (catalytic acid/base) for the protonation of oxygen atoms

253 from sugar molecules. Phylogenetic analysis revealed that CHI shares close evolutionary

254 relationships with chitinases from P. ehimensis and P. chitinolyticus (Fig. 3A). Comparisons

255 using the Protein Data Bank (PDB) revealed the homology of CHI and Chitinase ChiA 74 from

256 B. thuringiensis to be $62.40 \%$, with high matching accuracy. The results of homologous

257 modeling are illustrated in Fig. 3B.

\section{Effect of temperature and pH on enzyme activity and stability}

259 The determined temperature-activity profile of CHI is shown in Fig. 4A. Chitinase activity

260 increased gradually with increasing temperature from 25 to $45^{\circ} \mathrm{C}$; maximal activity was

261 observed at $45^{\circ} \mathrm{C}$. Relative enzyme activity of $>90 \%$ was retained at $50{ }^{\circ} \mathrm{C}$. Above $50{ }^{\circ} \mathrm{C}$, the

262 activity of CHI decreased markedly. The thermal stability of CHI is illustrated in Fig. 4B. The

263 enzyme was generally stable at $25-45^{\circ} \mathrm{C}$ for both periods of incubation. 
264 The effect of $\mathrm{pH}$ on the activity of $\mathrm{CHI}$ is shown in Fig. 4C. The highest activity was observed

265 within the $\mathrm{pH}$ range 4.0-8.0, with maximal activity recorded at $\mathrm{pH} 5.0$ (relative activities at $\mathrm{pH}$

2664.0 and 7.0 were $53.16 \%$ and $71.02 \%$ respectively). Activity at $\mathrm{pH} 8.0$ was higher in glycine-

$267 \mathrm{NaOH}$ than phosphate buffer. The effect of $\mathrm{pH}$ on CHI stability is shown in Fig. 4D. The

268 optimum $\mathrm{pH}$ for stability of this chitinase was 8.0 , but the enzyme was very stable within the $\mathrm{pH}$

269 range 4.0-10.0 (with relative activity of $>70 \%$ observed after incubation at $4{ }^{\circ} \mathrm{C}$ for $5 \mathrm{~h}$ ).

270 Effect of chemical reagents, metal ions, and solvents on enzyme activity and stability

271 The influence of metal ions and chemical reagents on the activity of purified CHI is shown in

272 Fig. 5. The presence of $\mathrm{Mn}^{2+}, \mathrm{Ca}^{2+}$ and urea significantly increased the activity of CHI. We found

273 that the activity of CHI was not significantly affected by $\mathrm{Mg}^{2+}, \mathrm{Na}^{+}, \mathrm{K}^{+}$, or $\mathrm{NH}_{4}{ }^{+}$in the present

274 study. When mixed with $10 \mathrm{mM} \mathrm{Co}{ }^{2+}$, Tris, or $\mathrm{Cd}^{2+}$, the residual activity of CHI was high, but

275 decreased moderately when these reagents were present at $50 \mathrm{mM}$. Relatively high activity

$276(>100 \%)$ was maintained in the presence of $10 \mathrm{mM} \mathrm{Ba}^{2+}$, although the activity dropped sharply

277 when the concentration of $\mathrm{Ba}^{2+}$ was increased to $50 \mathrm{mM}$. We found $\mathrm{CHI}$ activity to be strongly

278 inhibited at both tested concentrations of $\mathrm{Zn}^{2+}, \mathrm{Al}^{3+}, \mathrm{Ag}^{2+}$, and SDS (relative activity of $<60 \%$ in

279 each case). However, the presence of $\mathrm{Cu}^{2+}$ and $\mathrm{Fe}^{3+}$ obviously inhibited the activity of $\mathrm{CHI}$. We

280 also found that $10 \mathrm{mM}$ EDTA enhanced activity, while $50 \mathrm{mM}$ EDTA significantly reduced

281 activity.

282 The influence of various organic solvents on the stability of purified CHI is shown in Fig. 6; the

283 activity obviously increased in the presence of Tween 80 . In addition, CHI activity was 
284 moderately increased (relative activity $>100 \%$ ) in the presence of $10 \%$ chloroform, although

285 activity decreased sharply when $20 \%$ chloroform was used. Most of the organic solvents tested

286 in the present study; including methanol, ethanol, isopropanol, glycerin, and DMSO; caused CHI

287 activity to decrease somewhat when used at 10\% final concentration, while $20 \%$ organic solvent

288 markedly suppressed activity. However, $\beta$-mercaptoethanol, isoamyl alcohol, and acetic acid

289 strongly inhibited CHI activity (by $>50 \%$ ) at both concentrations.

290 Effect of $\mathrm{NaCl}$ concentration on enzyme activity

291 As Fig. 7 shows, the optimum salt concentration was found to be $1.5 \% \mathrm{NaCl}$. At higher

292 concentrations, chitinase activity decreased, reaching $<60 \%$ relative activity at $12.5 \% \mathrm{NaCl}$.

\section{Substrate specificity}

294 The specific activities of purified recombinant CHI toward different substrates are shown in

295 Table 2 . The highest specific activity was toward colloidal chitin $\left(567.2 \mathrm{mU} \mathrm{mg}^{-1}\right)$. The next

296 highest activity was observed when chitin powder was used as a substrate $\left(288.69 \mathrm{mU} \mathrm{mg}^{-1}\right)$; in

297 this case, the relative activity was $50.9 \% \pm 3.04 \%$ compared with colloidal chitin (100\%). No

298 activity was detected toward chitosan oligosaccharide (DDA > 90\%), carboxymethyl chitosan

$299(\mathrm{DDA} \geq 90 \%)$ or CMC-Na.

300 Mass spectrometry analysis of the hydrolysis product 
301 We used ESI-MS in positive ion mode to analyze the major products of colloidal chitin

302 hydrolysis by purified CHI, and the degradation mode of chitinase was inferred. As shown in

303 Figs. 8 and 9, peaks with $m / z$ of 244/260 (GlcNAc), 447/463 (GlcNAc) $)_{2}$ and 650 (GlcNAc) 3

304 were attributed to sodium, potassium, or hydrogen adducts of oligosaccharides with different

305 degrees of polymerization. ESI-MS analyses showed the major hydrolysis product of colloidal

306 chitin to be GlcNAc, with some (GlcNAc) 2 produced (Fig. 9).

\section{Discussion}

308 In this study, we cloned and heterologously expressed the CHI gene from marine-derived $P$.

309 chitinolyticus strain UMBR 0002, and functionally characterized the CHI properties and

310 products, with the aim of providing an increased understanding of the purified CHI activity in $P$.

311 chitinolyticus strain UMBR 0002, and benefiting to the extensive studies of marine-derived

312 bacteria as novel sources of chitinases for the green degradation of chitin waste. The majority of

313 previous studies on $P$. chitinolyticus have focused on the wild bacterium (Song et al., 2012;

314 Mihajlovski et al., 2017). However, cloning and expression of CHI from P. chitinolyticus strain

315 UMBR 0002 are rarely performed to study furtherly specific enzymatic properties. Therefore, in-

316 depth studies of the characteristics of P. chitinolyticus strain UMBR 0002 chitinase may enable

317 the development of procedures for the efficient degradation of chitin waste.

318 Most chitinases from Paenibacillus species are reported to be in the range of 38-153 kDa (Fu et

319 al., 2014); the molecular masse of CHI (approximately $80 \mathrm{kDa}$ ) in the present is close to

320 chitinases from other Paenibacillus species such as Paenibacillus sp. FPU-7 (61, 78, 82, 87,97, 
321 122, and $153 \mathrm{k} \mathrm{Da}$ (Itoh et al., 2013), P. ehimensis MA2012 (>100, 100,72, 65, 60, 50, 37, and

$32235 \mathrm{kDa}$ ) (Seo et al., 2016) and P. barengoltzii (about $74.6 \mathrm{kDa}$ ) (Fu et al., 2014). Interestingly,

323 the zymogram of mature CHI exhibited about two single bands surrounded by clear zones (Fig

324 1), similar to results of analysis of chitinase obtained from the Antarctic psychrotolerant

325 bacterium, Vibrio sp. strain Fi :7, which produced protein bands of 80 and $82 \mathrm{kDa}$ on the

326 zymogram (Bendt et al., 2001). The reason for the two bands observed in the present study

327 remains unclear, and requires further study. One possible explanation could be that CHI exists in

328 two isoforms (Bendt et al., 2001), as has been reported for two chitinases from Streptomyces sp.

329 (Okazaki et al., 1995).

$330 \mathrm{CHI}$ exhibited its optimum temperature at $45^{\circ} \mathrm{C}$, which was lower than hat reported for chitinase

331 from $P$. thermoaerophilus strain TC22-2b $\left(60^{\circ} \mathrm{C}\right)($ Ueda \& Kurosawa, 2015), but higher than

332 that of chitinase from P. pasadenensis NCIM $5434\left(37^{\circ} \mathrm{C}\right)$ (Loni et al., 2014). CHI showed high

333 stability, retaining more than $70 \%$ activity at $25-45^{\circ} \mathrm{C}$ (maximum of $90 \mathrm{~min}$ ), which is similar to

334 the results reported for chitinase from S. marcescens B4A (Emruzi et al., 2018). The charge

335 distribution of substrate and enzyme molecules can affect substrate binding and catalysis

336 (Bouacem et al., 2018). The optimum pH for chitinases from Hydrogenophilus hirschii strain

337 KB-DZ44 (Bouacem et al., 2018), Paenibacillus sp. D1 (Singh \& Chhatpar, 2011), and P.

338 illinoisensis strain KJA-424 (Jung et al., 2005) has been reported to be around 5.0, in line with

339 results of the present study; however, chitinases from Sulfolobus tokodaii (Staufenberger, Imhoff

340 \& Labes, 2012), P. thermoaerophilus strain TC22-2b (Ueda \& Kurosawa, 2015), S. antarcticus

Peer] reviewing PDF | (2019:10:42131:3:0:NEW 14 Mar 2020) 
341 KOPRI 21702 (Park et al., 2009), and P. pasadenensis NCIM 5434 (Loni et al., 2014) are

342 reported to exhibit maximum activity at $\mathrm{pH} 2.5,4.0,7.6$, and 10.0, respectively. The present

343 results indicate that $\mathrm{CHI}$ was highly stable at $\mathrm{pH} 4.0-10.0$ for $5 \mathrm{~h}$ at $4{ }^{\circ} \mathrm{C}$. This is similar to

344 chitinase from $P$. thermoaerophilus strain TC22-2b, which was reported to be stable at $\mathrm{pH} 4-10$

345 (Ueda \& Kurosawa, 2015), but a wider range than chitinase from P. barengoltzii (pH 4.0-9.0)

346 (Fu et al., 2014). The broad pH range and high pH stability suggest that CHI may be a good

347 candidate for industrial and commercial applications (Ueda \& Kurosawa, 2015). Metal ions play

348 an important role in biocatalysts by stabilizing substrate-enzyme complexes (Andreini et al.,

349 2008). Enzyme activity was enhanced by almost twofold in the presence of $10 \mathrm{mM} \mathrm{Mn}^{2+}$

350 compared with the control (no metal ions). This is similar to the results of a previous study

351 chitinase from Melghiribacillus thermohalophilus strain Nari2AT (Mohamed et al., 2019). We

352 also found that $\mathrm{Ca}^{2+}(10$ and $50 \mathrm{mM})$ and urea caused enzyme activity to increase. It is well

353 known that metal ions act as cofactors for enzyme activity and contribute to the maintenance of

354 enzyme structure by acting as ion or salt bridges (Kamran et al., 2015). Industrial extraction of

355 chitin usually involves the dissolve of minerals such as calcium carbonate from shrimp and crab

356 shells and releases $\mathrm{Ca}^{2+}$, followed by further processing to obtain valuable chitin derivatives.

357 Therefore, CHI can offer advantages in industrial application. The chitinase analyzed in this

358 study might resemble a chitinase from $P$. pasadenensis NCIM 5434, which was reported to be

359 increased by $\mathrm{Ca}^{2+}$ at $100 \mathrm{mM}$ concentration (Loni et al., 2014). This is in contrast with chitinase

360 from Glaciozyma antarctica PI12 (Ramli et al., 2011), which has been reported to be inhibited by 
$36110 \mathrm{mM} \mathrm{Ca}^{2+}$. In the present study, $\mathrm{CHI}$ activity was completely inhibited by $\mathrm{Cu}^{2+}$ and $\mathrm{Fe}^{3+}$;

362 heavy metal ions may denature enzymes by destroying the tertiary structure of the protein, thus

363 inactivating the molecules. This result is in line with observations of chitinase from $P$.

364 pasadenensis NCIM 5434, where enzymatic activity was completely inhibited by $\mathrm{Cu}^{2+}$ (Loni et

365 al., 2014). It has been suggested that $\mathrm{Cu}^{2+}$ catalyzes the autooxidation of cysteine, resulting in the

366 formation of intramolecular disulfide bonds or sulfonic acid, which may inhibit the activity of

367 chitinase (Deng et al., 2019). The influence of EDTA on purified CHI is consistent with

368 chitinase from Chitinolyticbacter meiyuanensis SYBC-H1 (Zhang et al., 2018), whose activity

369 was found to be enhanced by $10 \mathrm{mM}$ EDTA. As EDTA is a metal ion chelator EDTA, the effect

370 on enzyme activity indicates that $\mathrm{CHI}$ is not dependent on metal ions for enzymatic activity. The

371 reported effects of metallic ions on chitinases are diverse (Mohamed et al., 2019), and future

372 studies investigating the mechanism underlying the effects of metals on chitinase activity are

373 important. Organic solvents are used to solubilize hydrophobic substrates in enzymatic assays.

374 The activity of purified CHI was also obviously increased by the presence of Tween 80 , similar

375 to chitinase from S. thermodiastaticus HF 3-3 (Take et al., 2018). This indicates that Tween 80

376 reduces the activation energy of the reaction, promoting the enzymatic reaction. The effects of

377 many organic solvents in the study on purified CHI activity are similar to those relating to

378 chitinases produced by Streptomyces sp. (Karthik, Binod \& Pandey, 2015) and Aeromonas

379 hydrophila SBK1 (Halder et al., 2016). The stability of CHI in low concentrations of most

380 organic solvents indicates that hydrophobic interactions play an important role in enzymatic 
381 activity, and may make it possible to use this enzyme in practical industrial applications

382 (Mohamed et al., 2019). Salt-tolerant chitinases play important roles in industrial operations

383 (Karthik, Binod \& Pandey, 2015). Activity of CHI could be increased by addition of $\mathrm{NaCl}(0-3$

$384 \%$ ) in the reaction (Fig. 7). Moreover, more than $90 \%$ residual activity was recorded at $\mathrm{NaCl}$

385 concentrations of up to $4.5 \%$. The concentration of $\mathrm{NaCl}$ in seawater is about $3 \%$; thus, $\mathrm{CHI}$ may

386 have utility for the degradation of chitin waste from sea food and waste from marine and coastal

387 environments.

388 To examine the substrate specificity of CHI, various substrates were selected as shown in Table

389 2. Our results indicated that CHI preferred to colloidal chitin than chitin powder. Which indicates

390 that CHI can degrade colloidal chitin most readily of the tested substrates. This degradation may

391 be followed by further hydrolysis. The DDA of chitosan directly influences its biological

392 activities. A greater DDA reflects a larger number of positively charged amine groups in acidic

393 conditions (He et al., 2016). In the catalytic process of GH18 chitinase, the acid that protonates

394 the glycosidic linkage is a conserved glutamate and the nucleophile is the oxygen of the $\mathrm{N}$-acetyl

395 group on the -1 sugar and the reaction proceeds via an oxazolinium ion intermediate. Due to this

396 unusual enzymatic mechanism, a GlcNAc residue is required in the -1 subsite for catalytic

397 cleavage to occur (Hartl, Zach \& Seidl-Seiboth, 2012). This explains the lack of activity that we

398 detected toward chitosan oligosaccharide (DDA $>90 \%)$ and carboxymethyl chitosan (DDA $\geq$ 
$39990 \%$ ). We did not detect any activity toward CMC-Na, similar to chitinase from Aeromonas sp

400 No. 16 which cannot degrade CMC (Huang, Chen \& Su, 1996).

401 For a deeper understanding of the catalytic mechanism of CHI, the major products of colloidal

402 chitin hydrolyzed by purified CHI (Figs. 8 and 9) were examined by ESI-MS. Colloidal chitin

403 can become deacetylated under alkaline conditions; therefore, the presence of GlcNAc in Fig. 9

404 is unsurprising. After $0.5 \mathrm{~h}$ (Fig. 9A and 9B), considerable hydrolysis of colloidal chitin was

405 observed, producing GlcNAc and (GlcNAc) $)_{2}$ as the main products, and (GlcNAc) $)_{3}$ as a minor

406 product. This also indicates that $\mathrm{CHI}$ does not have endochitinase activity. At $1 \mathrm{~h}$ (Fig. $9 \mathrm{C}$ and

407 9D), the minor product, (GlcNAc) $)_{3}$, was not detected, and GlcNAc and (GlcNAc) $)_{2}$ were present

408 in seemingly equal amounts. From 6 to 14 h (Figs. 9E and 9H), the abundance of the dominant

409 product, GlcNAc, continued to increase, while the change of (GlcNAc) $)_{2}$ was not obvious in the

410 reaction system. These results suggest that, with sufficient degradation time, CHI can hydrolyze

411 substrates to produce (GlcNAc) as the major product and (GlcNAc) 2 as a minor product. The

412 products of colloidal chitin hydrolysis are consistent with the hydrolysates reported to be formed

413 by exochitinases derived from B. thuringiensis (Juárez-Hernández et al., 2019), which has the

414 highest similarity (62.40\%) to CHI from homology modeling. Therefore, CHI can be considered

415 to be an exochitinase with $\beta$-N-acetylglucosaminidase activity. The hydrolysis mechanism and

416 processing of $\mathrm{CHI}$ are similar to those of $\mathrm{PbChi74}$ from $P$. barengoltzii, which possesses two

417 chitinolytic activities (exochitinase and N-acetyl- $\beta$-glucosaminidase activities) (Fu et al., 2014).

418 However, the hydrolysis mechanism of $\mathrm{CHI}$ is different to that of an exochitinase (ChiC) from 
419 Pseudoalteromonas sp. DL-6, which was only found to have exochitinase activity requiring a

420 prolonged reaction time to hydrolyze colloidal chitin (Wang et al., 2016). An exochitinase of $S$.

421 speibonae TKU048 has been demonstrated to possess N-acetyl- $\beta$-glucosaminidase activity only

422 (Tran et al., 2019), while a novel chitinase (CmChi1) from Chitinolyticbacter meiyuanensis

423 SYBC-H1 is reported to possess both exo- and endochitinase abilities with poor N-acetyl- $\beta$ -

424 glucosaminidase activity (Zhang et al., 2018). Biological production is a valuable "green"

425 method for GlcNAc production; therefore, the hydrolysis activity of CHI may be beneficial for

426 industrial production of GlcNAc from chitin materials. Nevertheless, the specific catalytic

427 mechanism underlying the hydrolysis of chitin by CHI needs to be further studied.

\section{Conclusions}

429 In summary, we report the successful cloning and purification of a chitinase from $P$.

430 chitinolyticus strain UMBR 0002 using an E. coli Rosetta-gami B (DE3) expression system. The

431 enzyme, which was named CHI, had a molecular mass of approximately $80 \mathrm{kDa}$, and optimum

432 catalytic activity toward colloidal chitin at $45^{\circ} \mathrm{C}$ and $\mathrm{pH} 5.0$, respectively. Significant substrate

433 specificity toward colloidal chitin was identified, and ESI-MS analyses showed the major

434 hydrolysis product of colloidal chitin to be GlcNAc, with some (GlcNAc) 2 produced. Products

435 were obtained in a relatively short time, indicating that $\mathrm{CHI}$ is an exochitinase. High activity and

436 stability were observed over wide temperature, $\mathrm{pH}$, and $[\mathrm{NaCl}]$ ranges; furthermore, the presence

437 of $\mathrm{Ca}^{2+}$ and Tween 80 significantly increased chitinase activity. These properties make this 
438

439

440

441

442

443

444 for editing the English text of a draft of this manuscript.

\section{References} and could provide insight into other enzymes from this strain.

\section{Acknowledgements} 10.1007/s00775-008-0404-5. $10.1007 / \mathrm{s} 007920100179$. biotechnology 187(1):407-423 DOI 10.1007/s12010-018-2822-3. Biological Macromolecules 116:64-70 DOI 10.1016/j.ijbiomac.2018.05.014.

enzyme a promising candidate for green industrial conversion of chitinous waste to chitin

oligomers. Taken together, CHI could be exploited for biological and environmental applications in the future. The results presented here deepen our understanding of the Paenibacillus species

We thank Amy Phillips, PhD, from Liwen Bianji, Edanz Editing China (www.liwenbianji.cn/ac)

Andreini C, Bertini I, Cavallaro G, Holliday GL, Thornton JM. 2008. Metal ions in biological catalysis: from enzyme databases to general principles. JBIC Journal of Biological Inorganic Chemistry 13(8): 1205-1218 DOI

Bendt A, Hüller H, Kammel U, Helmke E, Schweder T. 2001. Cloning, expression, and characterization of a chitinase gene from the Antarctic psychrotolerant bacterium Vibrio sp. strain Fi:7. Extremophiles 5(2):119-126 DOI

Bouacem K, Laribi-Habchi H, Mechri S, Hacene H, Jaouadi B, Bouanane-Darenfed A. 2018. Biochemical characterization of a novel thermostable chitinase from Hydrogenophilus hirschii strain KB-DZ44. International Journal of Biological Macromolecules 106:338-350 DOI 10.1016/j.jbbiomac.2017.08.026.

Bradford MM. 1976. A rapid and sensitive method for the quantitation of microgram quantities of protein utilizing the principle of protein-dye binding. Analytical Biochemistry 72(1-2):248-254 DOI 10.1016/0003-2697(76)90527-3.

Das S, Dey P, Roy D, Maiti MK, Sen R. 2019. N-acetyl-D-glucosamine production by a chitinase of marine fungal origin: a case study of potential industrial significance for valorization of waste chitins. Applied biochemistry and

Deng JJ, Shi D, Mao HH, Li ZW, Liang S, Ke Y, Luo XC. 2019. Heterologous expression and characterization of an antifungal chitinase (Chit46) from Trichoderma harzianum GIM 3.442 and its application in colloidal chitin conversion. International Journal of Biological Macromolecules 134:113-121 DOI 10.1016/j.ijbiomac.2019.04.177. Emruzi Z, Aminzadeh S, Karkhane AA, Alikhajeh J, Haghbeen K, Gholami D. 2018. Improving the thermostability of Serratia marcescens B4A chitinase via G191V site-directed mutagenesis. International Journal of 
466 Fu X, Yan Q, Yang S, Yang X, Guo Y, Jiang Z. 2014. An acidic, thermostable exochitinase with $\beta-N-$

467 acetylglucosaminidase activity from Paenibacillus barengoltzii converting chitin to N-acetyl glucosamine.

468 Biotechnology for biofuels 7(1): 174 DOI 10.1186/s13068-014-0174-y.

469 Guo N, Sun J, Wang W, Gao L, Liu J, Liu Z, Xue C, Mao X. 2019. Cloning, expression and characterization of a

470 novel chitosanase from Streptomyces albolongus ATCC 27414. Food Chemistry 286: 696-702 DOI

471 10.1016/j.foodchem.2019.02.056.

472 Halder SK, Jana A, Paul T, Das A, Ghosh K, Pati BR, Mondal KC. 2016. Purification and biochemical

473 characterization of chitinase of Aeromonas hydrophila SBK1 biosynthesized using crustacean shell. Biocatalysis

474 and Agricultural Biotechnology 5:211-218 DOI 10.1016/j.bcab.2015.11.003.

475 Hamed I, Özogul F, Regenstein JM. 2016. Industrial applications of crustacean by-products (chitin, chitosan, and 476 chitooligosaccharides): A review. Trends in Food Science \& Technology 48:40-50 DOI 10.1016/j.tifs.2015.11.007.

477 Hamid R, Khan MA, Ahmad M, Ahmad MM, Abdin MZ, Musarrat J, Javed S. 2013. Chitinases: An update.

478 Journal of Pharmacy \& BioAllied Sciences 5(1): 21-29 DOI 10.4103/0975-7406.106559.

479 Han Y, Yang B, Zhang F, Miao X, Li Z. 2009. Characterization of antifungal chitinase from marine Streptomyces 480 sp. DA11 associated with South China Sea sponge Craniella australiensis. Marine Biotechnology 11(1):132 DOI 481 10.1007/s10126-008-9126-5.

482 Hartl L, Zach S, Seidl-seiboth V. 2012. Fungal chitinases: diversity, mechanistic properties and biotechnological 483 potential. Applied Microbiology and Biotechnology 93(2):533-543 DOI 10.1007/s00253-011-3723-3.

484 He X, Li K, Xing R, Liu S, Hu L, Li P. 2016. The production of fully deacetylated chitosan by compression 485 method. Egyptian Journal of Aquatic Research 42:75-81 DOI 10.1016/j.ejar.2015.09.003.

486 Huang JH, Chen CJ, Su YC. 1996. Production of chitinolytic enzymes from a novel species of Aeromonas.

487 Journal of Industrial Microbiology 17(2):89-95 DOI 10.1007/BF01570049.

488 Itoh T, Hibi T, Fujii Y, Sugimoto I, Fujiwara A, Suzuki F, Iwasaki Y, Kim JK, Taketo A, Kimoto H. 2013.

489 Cooperative degradation of chitin by extracellularand cell surface-expressed chitinases from Paenibacillus sp. strain 490 FPU-7. Applied and Environmental Microbiology 79(23): 7482-7490. DOI 10.1128/AEM.02483-13.

491 Jiang FY, Shui BB , Tang FX, Shan CH. 2017. Cloning and expression of class I chitinases in Hami melon after

492 Penicillium infection. Genetics and Molecular Research 16(1): gmr16019085 DOI 10.4238/gmr16019085.

493 Juárez-Hernández EO, Casados-Vázquez LE, Brieba LG, Torres-Larios A, Jimenez-Sandoval P, Barboza-

494 Corona JE. 2019. The crystal structure of the chitinase ChiA74 of Bacillus thuringiensis has a multidomain

495 assembly. Scientific reports 9(1):2591 DOI 10.1038/s41598-019-39464-z.

496 Jung WJ, Kuk JH, Kim KY, Kim TH, Park RD. 2005. Purification and characterization of chitinase from

497 Paenibacillus illinoisensis KJA-424. Journal of Microbiology and Biotechnology 15(2):274-280.

498 Kamran A, Rehman HU, Qader SAU, Baloch AH, Kamal M. 2015. Purification and characterization of thiol

499 dependent, oxidation-stable serine alkaline protease from thermophilic Bacillus sp. Journal of Genetic Engineering

500 and Biotechnology 13(1):59-64 DOI 10.1016/j.jgeb.2015.01.002.

501 Karthik N, Binod P, Pandey A. 2015. Purification and characterisation of an acidic and antifungal chitinase

502 produced by a Streptomyces sp. Bioresource Technology 188:195-201 DOI 10.1016/j.biortech.2015.03.006.

503 Kidibule PE, Santos-Moriano P, Jiménez-Ortega E, Ramírez-Escudero M, Limón MC, Remacha M, Plou FJ,

504 Sanz-Aparicio J, Fernández-Lobato M. 2018. Use of chitin and chitosan to produce new chitooligosaccharides by

Peer] reviewing PDF | (2019:10:42131:3:0:NEW 14 Mar 2020) 
505 chitinase Chit42: enzymatic activity and structural basis of protein specificity. Microbial Cell Factories 17(1):47

506 DOI 10.1186/s12934-018-0895-x.

507 Laribi-Habchi H, Bouanane-Darenfed A, Drouiche N, Pauss A, Mameri N. 2015. Purification, characterization,

508 and molecular cloning of an extracellular chitinase from Bacillus licheniformis stain LHH100 isolated from

509 wastewater samples in Algeria. International Journal of Biological Macromolecules 72:1117-1128 DOI

510 10.1016/j.ijbiomac.2014.10.035.

511 Le B, Yang SH. 2019. Microbial chitinases: properties, current state and biotechnological applications. World

512 Journal of Microbiology and Biotechnology 35(9): 144 DOI 10.1007/s11274-019-2721-y.

513 Li AN, Yu K, Liu HQ, Zhang J, Li H, Li DC. 2010. Two novel thermostable chitinase genes from thermophilic

514 fungi: cloning, expression and characterization. Bioresource Technology 101(14):5546-5551 DOI

515 10.1016/j.biortech.2010.02.058.

516 Liu SH, Li HF, Yang Y, Yang RL, Yang WJ, Jiang HB, Dou W, Smagghe G, Wang JJ. 2018. Genome-wide

517 identification of chitinase and chitin deacetylase gene families in the oriental fruit fly, Bactrocera dorsalis (Hendel).

518 Comparative Biochemistry and Physiology Part D: Genomics and Proteomics 27:13-22 DOI

519 10.1016/j.cbd.2018.04.005.

520 Loni PP, Patil JU, Phugare SS, Bajekal SS. 2014. Purification and characterization of alkaline chitinase from

521 Paenibacillus pasadenensis NCIM 5434. Journal of Basic Microbiology 54(10): 1080-1089 DOI

522 10.1002/jobm.201300533.

523 Meena S, Gothwal RK, Mohan MK, Ghosh P. 2014. Production and purification of a hyperthermostable chitinase

524 from Brevibacillus formosus BISR-1 isolated from the Great Indian Desert soils. Extremophiles 18(2): 451-462 DOI

$525 / 10.1007 / \mathrm{s} 00792-014-0630-4$.

526 Menghiu G, Ostafe V, Prodanovic R, Fischer R, Ostafe R. 2019. Biochemical characterization of chitinase A

527 from Bacillus licheniformis DSM8785 expressed in Pichia pastoris KM71H. Protein Expression and Purification

528 154:25-32 DOI 10.1016/j.pep.2018.09.007.

529 Mihajlovski KR, Davidović SZ, Veljović ĐN, Carević MB, Lazić VM, Dimitrijević-Branković SI. 2017.

530 Effective valorisation of barley bran for simultaneous cellulase and $\beta$-amylase production by Paenibacillus

531 chitinolyticus CKS1: Statistical optimization and enzymes application. Journal of the Serbian Chemical Society

532 82(11): 1223-1236 DOI 10.2298/JSC170514092M.

533 Miller GL. 1959. Use of Dinitrosalicylic Acid Reagent for Determination of Reducing Sugar. Analytical

534 Biochemistry 31(3):426-428 DOI 10.1021/ac60147a030.

535 Mohamed S, Bouacem K, Mechri S, Addou NA, Laribi-Habchi H, Fardeau ML, Jaouadi B, Bouanane-

536 Darenfed A, Hacène H. 2019. Purification and biochemical characterization of a novel acido-halotolerant and

537 thermostable endochitinase from Melghiribacillus thermohalophilus strain Nari2AT. Carbohydrate Research

538 473:46-56 DOI 10.1016/j.carres.2018.12.017.

539 Nawani NN, Kapadnis BP, Das AD, Rao AS, Mahajan SK. 2002. Purification and characterization of a

540 thermophilic and acidophilic chitinase from Microbispora sp. V2. Journal of Applied Microbiology 93(6): 965-975

541 DOI 10.1046/j.1365-2672.2002.01766.x. 
542 Noby N, Saeed H, Embaby AM, Pavlidis IV, Hussein A. 2018. Cloning, expression and characterization of cold 543 active esterase (EstN7) from Bacillus cohnii strain N1: A novel member of family IV. International Journal of

544 Biological Macromolecules 120:1247-1255 DOI 10.1016/j.ijbiomac.2018.07.169.

545 Okazaki K, Kato F, Watanabe N, Yasuda S, Masui Y, Hayakawa S. 1995. Purification and properties of two

546 chitinases from Streptomyces sp. J-13-3. Bioscience Biotechnology and Biochemistry 59(8):1586-1587 DOI

$54710.1271 / \mathrm{bbb} .59 .1586$.

548 Park HJ, Kim D, Kim IH, Lee CE, Kim I-C, Kim JY, Kim SJ, Lee HK, Yim JH. 2009. Characteristics of cold549 adaptive endochitinase from Antarctic bacterium Sanguibacter antarcticus KOPRI 21702. Enzyme and Microbial

550 Technology 45(5): 391-396 DOI 10.1016/j.enzmictec.2009.07.002.

551 Rameshthangam P, Solairaj D, Arunachalam G, Ramasamy P. 2018. Chitin and Chitinases: Biomedical and

552 environmental applications of chitin and its derivatives. Journal of Enzymes 1(1): 20-43.

553 Ramli ANM, Mahadi NM, Rabu A, Murad AMA, Bakar FDA, Illias RM. 2011. Molecular cloning, expression 554 and biochemical characterisation of a cold-adapted novel recombinant chitinase from Glaciozyma antarctica PI12.

555 Microbial Cell Factories 10(1):94 DOI 10.1186/1475-2859-10-94.

556 Salas-Ovilla R, Gálvez-López D, Vázquez-Ovando A, Salvador-Figueroa M, Rosas-Quijano R. 2019.

557 Isolation and identification of marine strains of Stenotrophomona maltophilia with high chitinolytic activity. PeerJ

558 7:e6102 DOI 10.7717/peerj.6102.

559 Seo DJ, Lee YS, Kim KY, Jung WJ. 2016. Antifungal activity of chitinase obtained from Paenibacillus ehimensis

560 MA2012 against conidial of Collectotrichum gloeosporioides in vitro. Microbial Pathogenesis 96:10-14 DOI

$56110.1016 /$ j.micpath.2016.04.016.

562 Singh AK, Chhatpar HS. 2011. Purification and characterization of chitinase from Paenibacillus sp. D1.

563 Applied Biochemistry and Biotechnology 164(1):77-88 DOI 10.1007/s12010-010-9116-8.

564 Song YS, Seo DJ, Kim KY, Park RD, Jung WJ. 2012. Expression patterns of chitinase produced from

565 paenibacillus chitinolyticus with different two culture media. Carbohydrate Polymers 90(2): 1187-1192 DOI

566 10.1016/j.carbpol.2012.06.016.

567 Staufenberger T, Imhoff JF, Labes A. 2012. First crenarchaeal chitinase found in Sulfolobus tokodaii.

568 Microbiological Research 167(5):262-269 DOI 10.1016/j.micres.2011.11.001.

569 Stoykov YM, Pavlov AI, Krastanov AI. 2015. Chitinase biotechnology: Production, purification, and application.

570 Engineering in Life Sciences 15(1):30-38 DOI 10.1002/elsc.201400173.

571 Take K, Fujiki H, Suyotha W, Hayashi J, Takagi K, Yano S, Wakayama M. 2018. Enzymatic and molecular

572 characterization of an acidic and thermostable chitinase 1 from Streptomyces thermodiastaticus HF 3-3. The Journal

573 of general and applied microbiology 64(4):190-197 DOI 10.2323/jgam.2017.12.002.

574 Tran TN, Doan CT, Nguyen MT, Nguyen VB, Vo TPK, Nguyen AD, Wang SL. 2019. An Exochitinase with N-

575 Acetyl- $\beta$-Glucosaminidase-Like Activity from Shrimp Head Conversion by Streptomyces speibonae and Its

576 Application in Hydrolyzing $\beta$-Chitin Powder to Produce N-Acetyl-d-Glucosamine. Polymers 11(10): 1600. DOI

577 10.3390/polym11101600.

578 Ueda J, Kurosawa N. 2015. Characterization of an extracellular thermophilic chitinase from Paenibacillus

579 thermoaerophilus strain TC22-2b isolated from compost. World Journal of Microbiology and Biotechnology

580 31(1): 135-143 DOI 10.1007/s11274-014-1754-5.

Peer) reviewing PDF | (2019:10:42131:3:0:NEW 14 Mar 2020) 
581 Vaikuntapu PR, Rambabu S, Madhuprakash J, Podile AR. 2016. A new chitinase-D from a plant growth

582 promoting Serratia marcescens GPS5 for enzymatic conversion of chitin. Bioresource Technology 220:200-207

583 DOI 10.1016/j.biortech.2016.08.055.

584 Wang D, Li A, Han H, Liu T, Yang Q. 2018. A potent chitinase from Bacillus subtilis for the efficient

585 bioconversion of chitin-containing wastes. International Journal of Biological Macromolecules 116:863-868 DOI

586 10.1016/j.ijbiomac.2018.05.122.

587 Wang X, Chi N, Bai F, Du Y, Zhao Y, Yin H. 2016. Characterization of a cold-adapted and salt-tolerant exo-

588 chitinase (ChiC) from Pseudoalteromonas sp. DL-6. Extremophiles 20(2): 167-176 DOI 10.1007/s00792-016-0810-

5895.

590 Yang CY, Ho YC, Pang JC, Huang SS, Tschen JSM. 2009. Cloning and expression of an antifungal chitinase

591 gene of a novel Bacillus subtilis isolate from Taiwan potato field. Bioresource Technology 100(3): 1454-1458 DOI

$59210.1016 /$ j.biortech.2008.07.039.

593 Zhang A, He Y, Wei G, Zhou J, Dong W, Chen K, Ouyang P. 2018. Molecular characterization of a novel

594 chitinase CmChi1 from Chitinolyticbacter meiyuanensis SYBC-H1 and its use in N-acetyl-d-glucosamine

595 production. Biotechnology for Biofuels 11(1):179 DOI 10.1186/s13068-018-1169-x.

596 Zhou J, Chen J, Xu N, Zhang A, Chen K, Xin F, Zhang W, Ma Z, Fang Y, Jiang M, Dong W. 2019. The broad-

597 specificity chitinases: their origin, characterization, and potential application. Applied Microbiology and

598 Biotechnology 103(8): 3289-3295 DOI 10.1007/s00253-019-09718-x. 
Table $\mathbf{1}$ (on next page)

Table 1: Chitinase purification. 


\begin{tabular}{|c|c|c|c|c|c|c|c|}
\hline Purification step & $\begin{array}{l}\text { Volume } \\
(\mathrm{mL})\end{array}$ & $\begin{array}{l}\text { Protein concentration } \\
\quad\left(\mathrm{mg} \mathrm{mL}^{-1}\right)\end{array}$ & $\begin{array}{l}\text { Enzyme activity } \\
\qquad\left(\mathrm{mU} \mathrm{mL}^{-1}\right)\end{array}$ & $\begin{array}{l}\text { Specific activity } \\
\qquad\left(\mathrm{mU} \mathrm{mg}^{-1}\right)\end{array}$ & $\begin{array}{c}\text { Total activity } \\
(\mathrm{mU})\end{array}$ & $\begin{array}{l}\text { Purification } \\
\text { (fold) }\end{array}$ & $\begin{array}{c}\text { Yield\% } \\
\text { (totala ctivity) }\end{array}$ \\
\hline $\begin{array}{c}\text { Crude enzyme } \\
\text { solution }\end{array}$ & 20 & 4.16 & 233.8 & 56.19 & 4676.1 & 1 & 100 \\
\hline $\begin{array}{l}\text { Ni-NTA affinity } \\
\text { chromatography }\end{array}$ & 2 & 2.25 & 1688.12 & 750.64 & 3376.25 & 13.36 & 72.2 \\
\hline
\end{tabular}

1

2 


\section{Table 2 (on next page)}

Table 2: Substrate specificity of chitinase from Paenibacillus chitinolyticus strain UMBR 0002 .

a: Experiments were conducted three times and standard errors are reported. b: Relative enzyme activity calculation using colloidal chitin as the reference value (100\%).

Abbreviations: CMC-Na, carboxymethyl cellulose sodium salt. 


\begin{tabular}{lcc}
\hline Substrate & Specific activity $^{\mathrm{a}}\left(\mathrm{mU} \mathrm{mg}^{-1}\right)$ & Relative percent activity $(100 \%)$ \\
\hline Colloidal chitin & $567.2 \pm 34.48$ & $100 \pm 6.08$ \\
Chitin powder & $288.69 \pm 17.22$ & $50.9 \pm 3.04$ \\
Chitosan oligosaccharide & 0 & 0 \\
Carboxymethyl chitosan & 0 & 0 \\
CMC-Na & 0 & 0 \\
\hline
\end{tabular}

1 


\section{Figure 1}

Figure 1: Representative gel of purification steps of chitinase from Paenibacillus chitinolyticus strain UMBR 0002.

M: Protein molecular weight markers. 1: Crude extract of Escherichia coli expressing chitinase purified from Paenibacillus chitinolyticus strain UMBR 0002 (CHI). 2: Unbound protein 3: Protein eluted with buffer containing $20 \mathrm{mM}$ imidazole. 4: Protein eluted with buffer containing $60 \mathrm{mM}$ imidazole. 5: Protein eluted with buffer containing $150 \mathrm{mM}$ imidazole. 6: Protein eluted with buffer containing $250 \mathrm{mM}$ imidazole. The gel was stained with Coomassie Brilliant Blue R-250. 

M
12
3
4.
5
6

\section{0 \\ 130 \\ 100 \\ 70 \\ 55 \\ 40 \\ 35 \\ 25}

15 


\section{Figure 2}

Figure 2: Domain architectures and multiple sequence alignment of chitinase from Paenibacillus chitinolyticus strain UMBR 0002.

(A) Domain structures of chitinase from Paenibacillus chitinolyticus strain UMBR 0002. Protein sequence analysis was carried out using BLASTP on NCBI. The locations of the following domains are indicated: GH18_chitinase (aa: 36-445; Accession, cd06548); fibronectin type III (FN3; aa:477-547; Accession, smart00060); fibronectin type III (FN3; aa: 571-653; Accession, cd00063 ), CBD_II (CBD_II; aa:670-785, Accession, smart00637). (B) Deduced amino acid sequence alignment of open reading frames of chitinase with chitinases from other species. Green boxes indicate the two conserved motifs KxxxxxGGW and FDGxDLDWEYP; red boxes are typical conserved modules of the glycoside hydrolase family 18, SxGG and DxxDxDxE. The yellow E indicates glutamic acid.

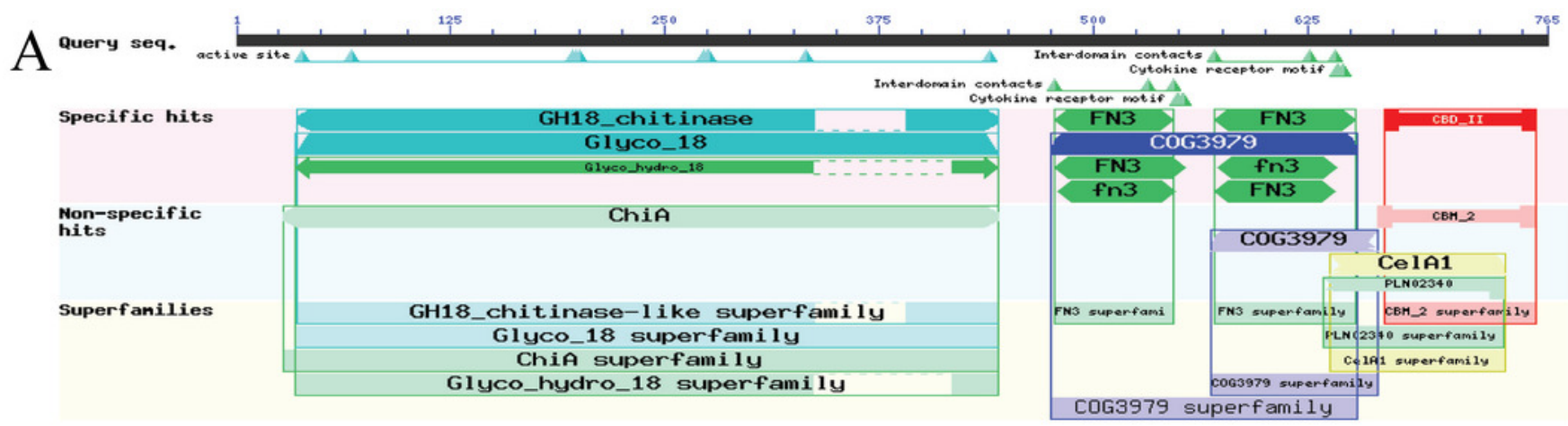

B WP_138185770.1 BAM67139. 1 WP_088042647.1 WP_068776920. 1 $\mathrm{CHI}$ WP_103996460. 1 WP_009676326. 1 WP_042235807. 1 BAC76694. 1
PHLKTLFSVGGWTWSNRFSDVAANEQYRVNFAKSAVDAIREYGFDGIDIDWEYPGVEGIK PHLKTI ISVGGWTWSNRFSDVAASAATRQTFAKSAVQFLRTYGFDGVDLDWEYPVSGGLT PHLKT I IS IGGWTWSNRFSDVAADPATRLVFAKSAVEF IRTYGFDGVDLDWEYPVSGGLS PSLKTLISVGGWTWSNRFSETAASAATRETFANSAVEFIRAYGFDGVDLDWEYPVAGGLA PSLKTLISVGGWTWSNRFSDVAANAATRETFANSAVEFIRTYGFDGVDLDWEYPVAGGLS PSLKTLISVGGWTWSNRFSETAASAATRETFANSAVEFIRTYGFDGVDLDWEYPVAGGLS PSLKTLISVGGWTWSNRFSDVAANATTRETFANSAVEFIRTYGFDGVDLDWEYPVAGGLS PSLKTLISVGGWTWSNRFSDVAANAATRETFANSAVEFIRTYGFDGVDLDWEYPVAGGLS PSLKTLISVGGWTWSNRFSDVAANAATRETFANSAVEFIRTYGFDGVDLDWEYPVAGGLS

* ***::*:**********:. **. * ***:***: :******:*:***** * Motif 1 


\section{Figure 3}

Figure 3: Phylogenetic analysis and homology model of chitinase from Paenibacillus chitinolyticus strain UMBR 0002.

(A) Amino acid sequence similarity tree based on sequences of proteins from glycoside hydrolase family $18(n=16)$. The phylogenetic tree was constructed using the neighborjoining option of ClustalW software. GenBank accession number for chitinase gene from Paenibacillus chitinolyticus strain UMBR 0002: MN121846. (B) Three-dimensional (3D) structure model of chitinase from Paenibacillus chitinolyticus strain UMBR 0002.

A

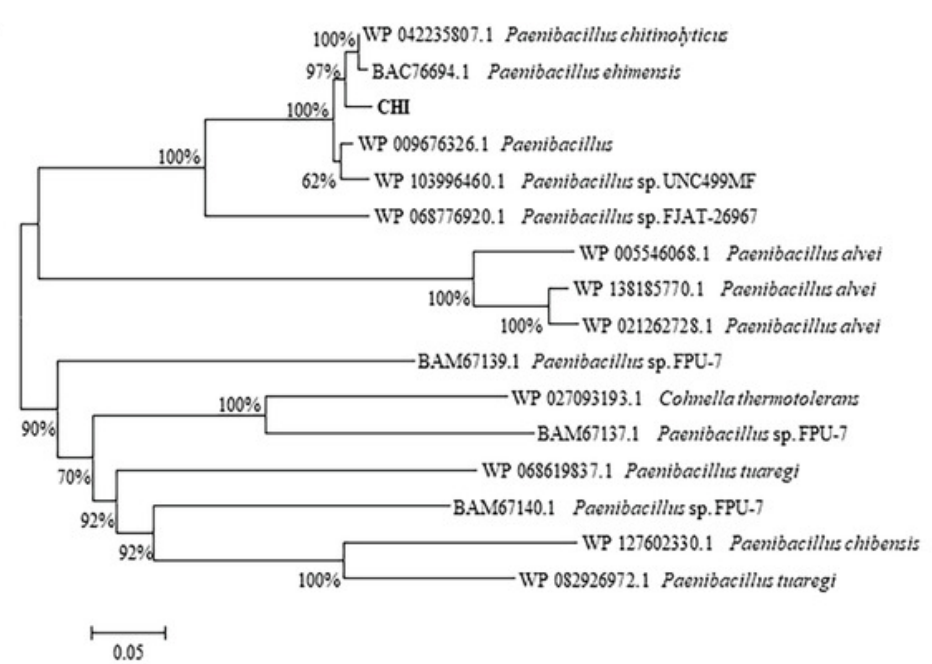

B

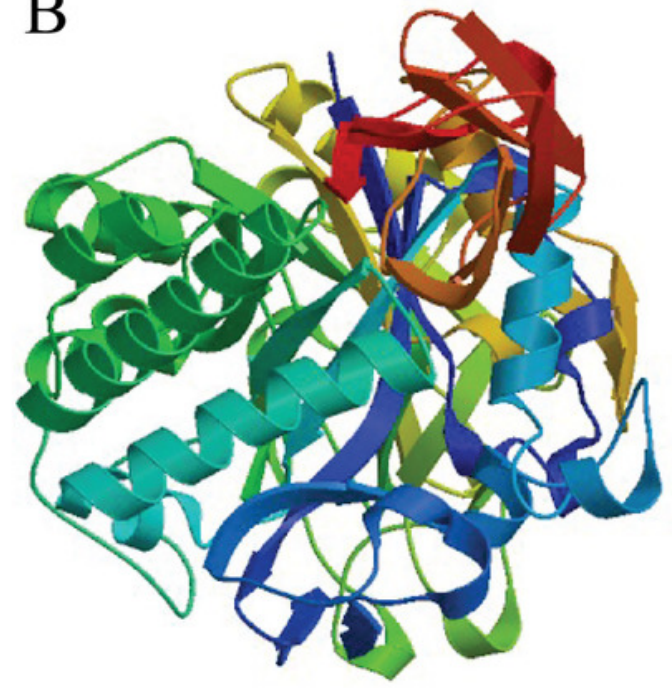




\section{Figure 4}

Figure 4: Effects of temperature and $\mathrm{pH}$ on the activity and stability of chitinase from Paenibacillus chitinolyticus strain UMBR 0002.

(A) The optimum temperature for activity of chitinase from Paenibacillus chitinolyticus strain UMBR 0002 (CHI) toward colloidal chitin at pH 7.0. The activity of the enzyme at $45^{\circ} \mathrm{C}$ was defined as $100 \%$. (B) Thermostability of $\mathrm{CHI}$ at pH 7.0. Activity of the non-heated enzyme was defined as $100 \%$. (C) Activity of $\mathrm{CHI}$ toward colloidal chitin at various $\mathrm{pH}$ levels at $45^{\circ} \mathrm{C}$. The activity of the enzyme at pH 5.0 was defined as $100 \%$. (D) Stability of $\mathrm{CHI}$ after incubation at various $\mathrm{pH}$ levels at $4{ }^{\circ} \mathrm{C}$ for $5 \mathrm{~h}$. The activity of the enzyme after incubation at $\mathrm{pH} 8.0$ (in phosphate buffer) was defined as $100 \%$. Each data point represents the mean of three independent experiments, standard errors are shown. 
A

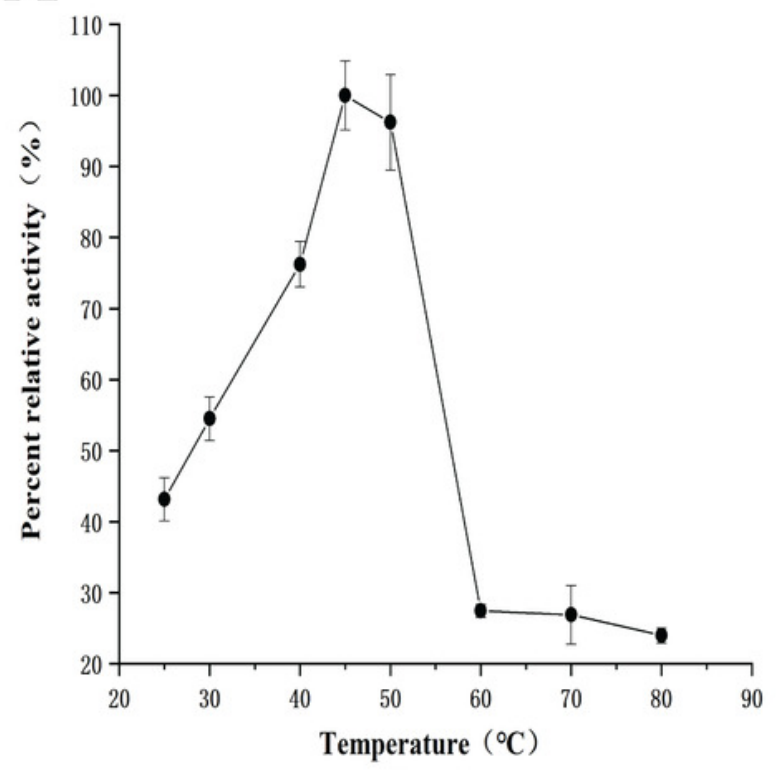

C

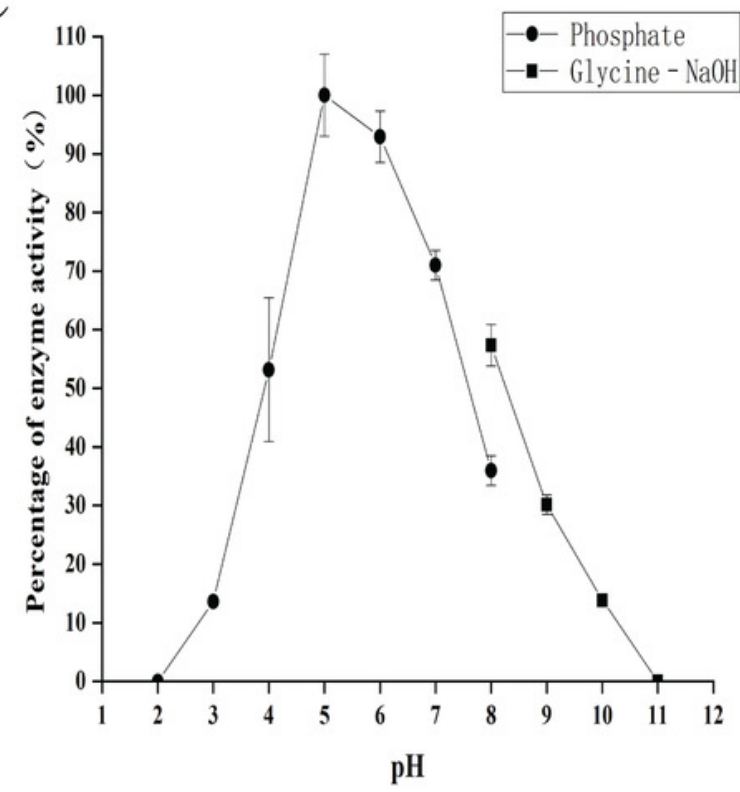

B

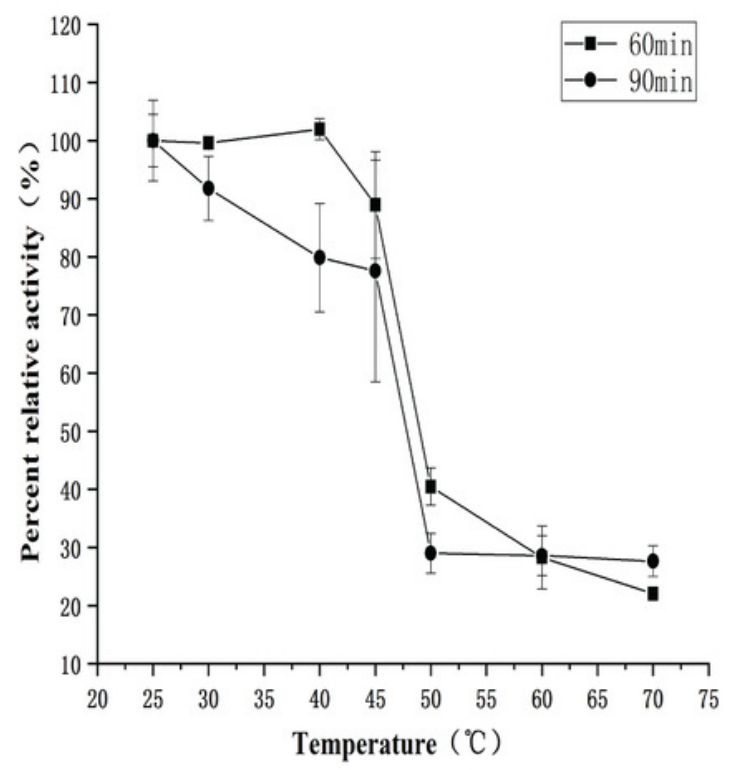

D

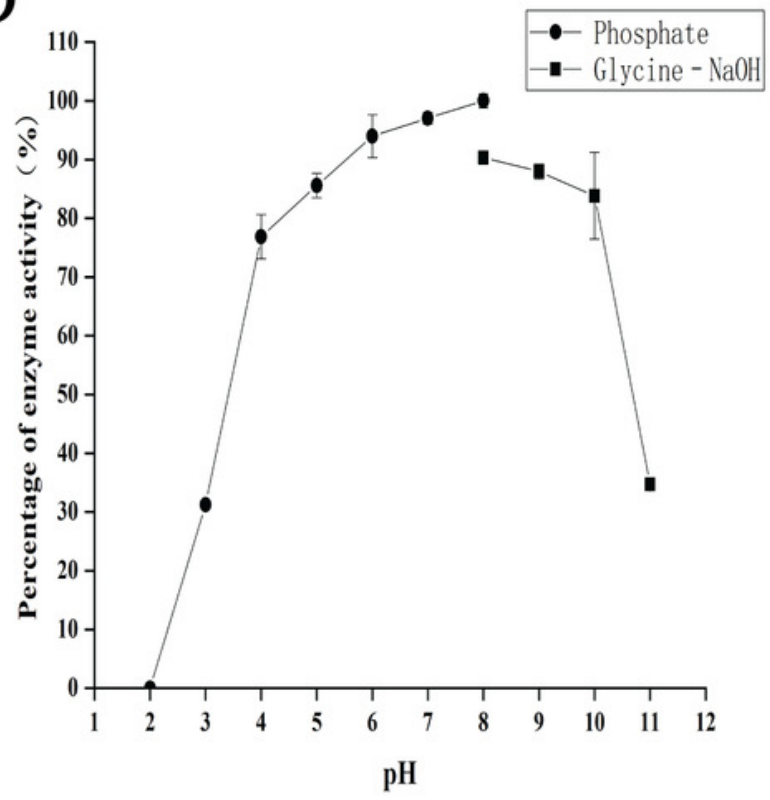


Figure 5

Figure 5: Effects of chemical reagents and metal ions on activity of chitinase from Paenibacillus chitinolyticus strain UMBR 0002.

Untreated enzyme was used as the control, and the activity of this preparation defined as 100\%. Experiments were carried out in triplicate and standard errors are shown.

Abbreviatios: EDTA, ethylenediaminetetraacetic acid; SDS, sodium dodecyl sulfate.

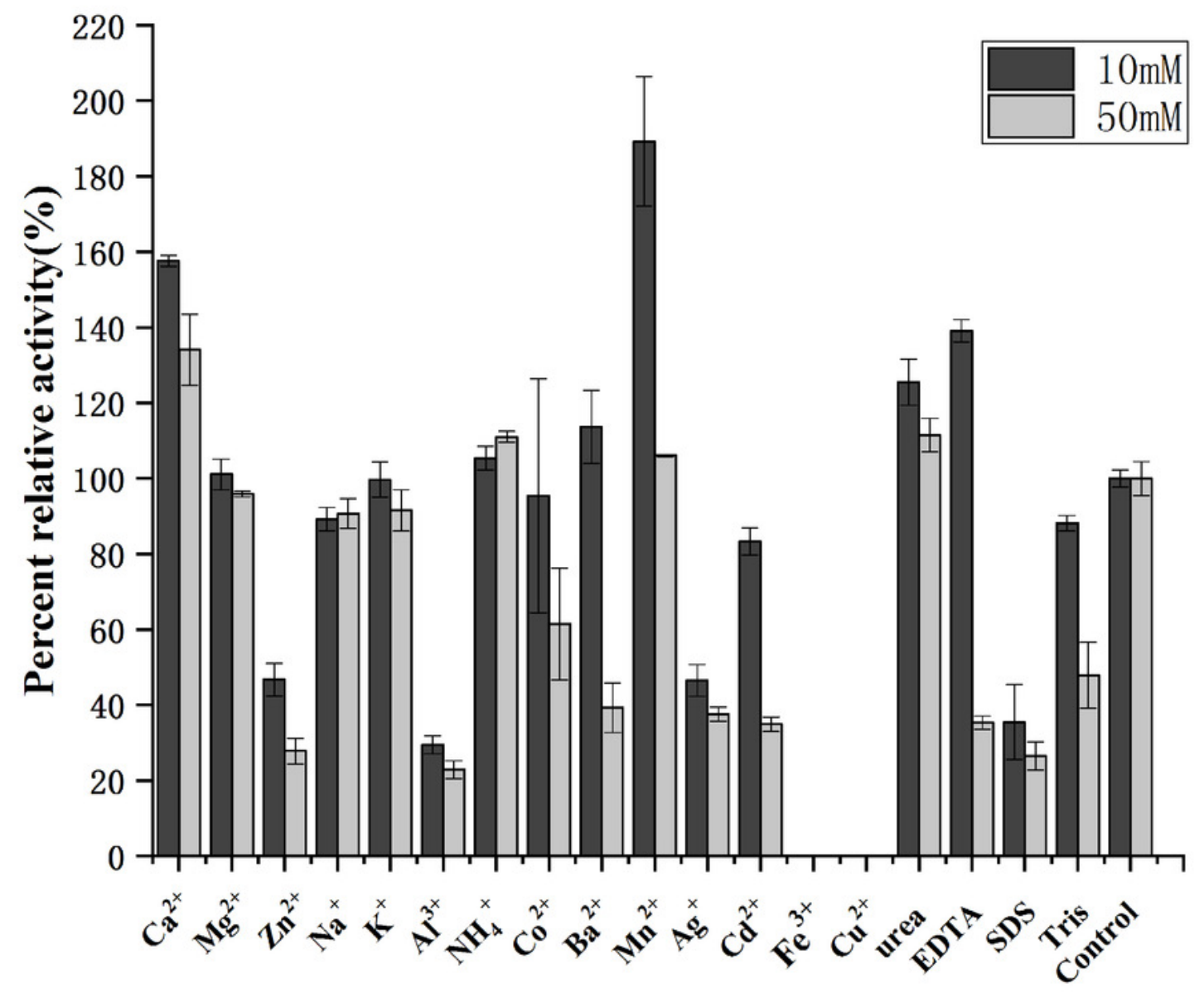

Chemical reagment/metallicions 


\section{Figure 6}

Figure 6: Effect of solvents on the activity of chitinase from Paenibacillus chitinolyticus strain UMBR 0002.

Untreated enzyme was used as the control (defined as 100\% activity). Experiments were carried out in triplicate and standard errors are shown. Abbreviations: DMSO, dimethylsulfoxide.

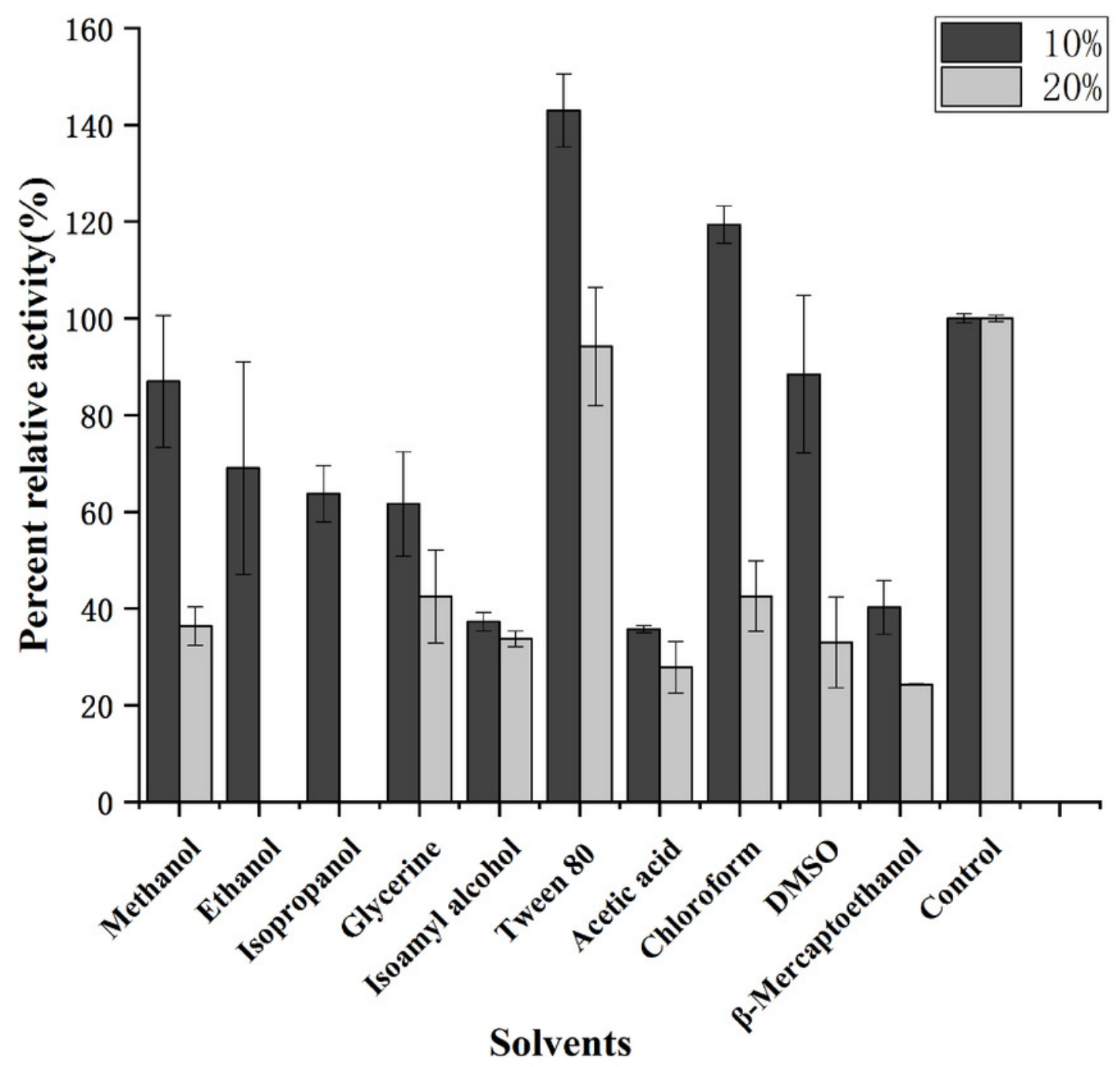


Figure 7

Figure 7: Effect of salt concentration on the activity of chitinase from Paenibacillus chitinolyticus strain UMBR 0002.

Untreated enzyme was used as the control and defined as $100 \%$ relative activity.

Experiments were carried out in triplicate and standard errors are shown.

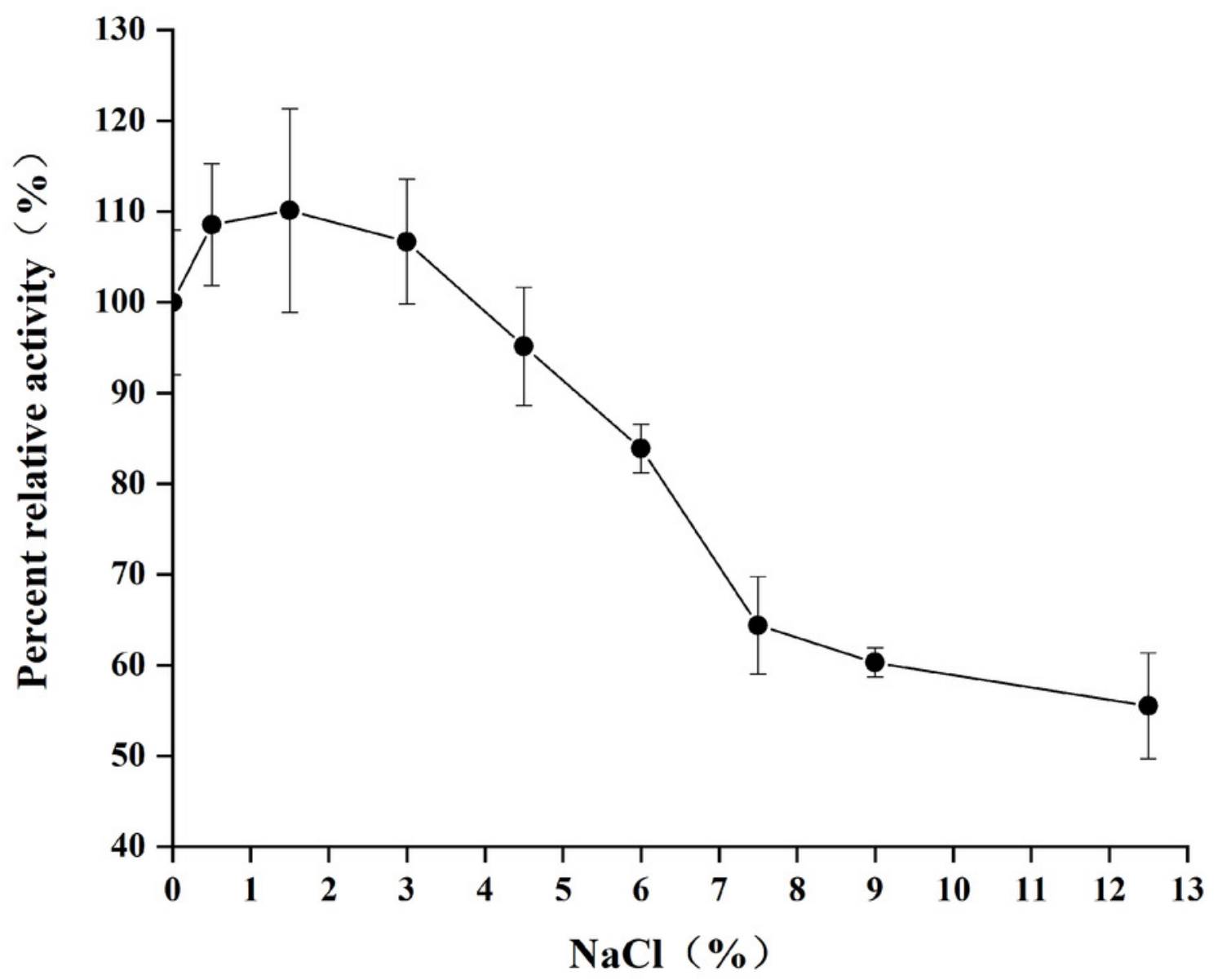


Figure 8

Firgue 8: Electrospray ionization-mass spectrometry spectrum of colloidal chitin.

+TOF MS: Exp 1,0.1284 min from Sample 1 (ji ding zhi) of jidingzhi(pos).wiff

Max. $2.665 \mathrm{cps}$

$a=7.02077644230924530 \mathrm{e}-004$, t0 $=1.55618184104876180 \mathrm{e}-001$ (DuoSpray ())

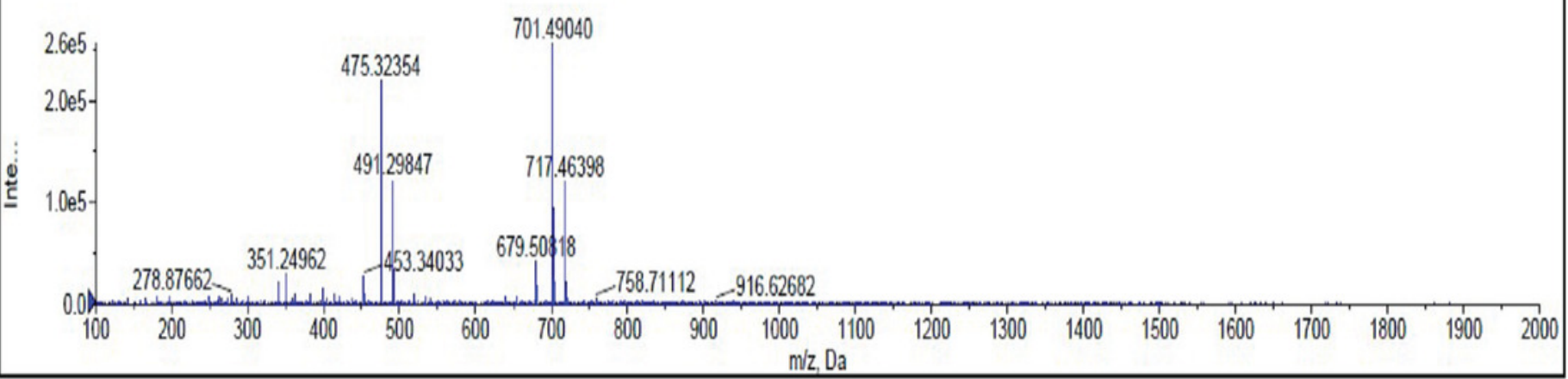




\section{Figure 9}

Firgue 9: Electrospray ionization-mass spectrometry spectra of products of hydrolysis of colloidal chitin by chitinase from Paenibacillus chitinolyticus strain UMBR 0002.

Products of enzymatic hydrolysis were analyzed after incubation for (A, B): $0.5 \mathrm{~h},(C, D): 1 \mathrm{~h}$, $(E, F): 6 h$, and $(G, H): 14$ h. Peak 1: (GlcNAc); 2: $(G l c N A c)_{2} ;$ 3: $(G \mid c N A c)_{3}$. Abbreviations: GIcNAc, N-acetylglucosamine. 

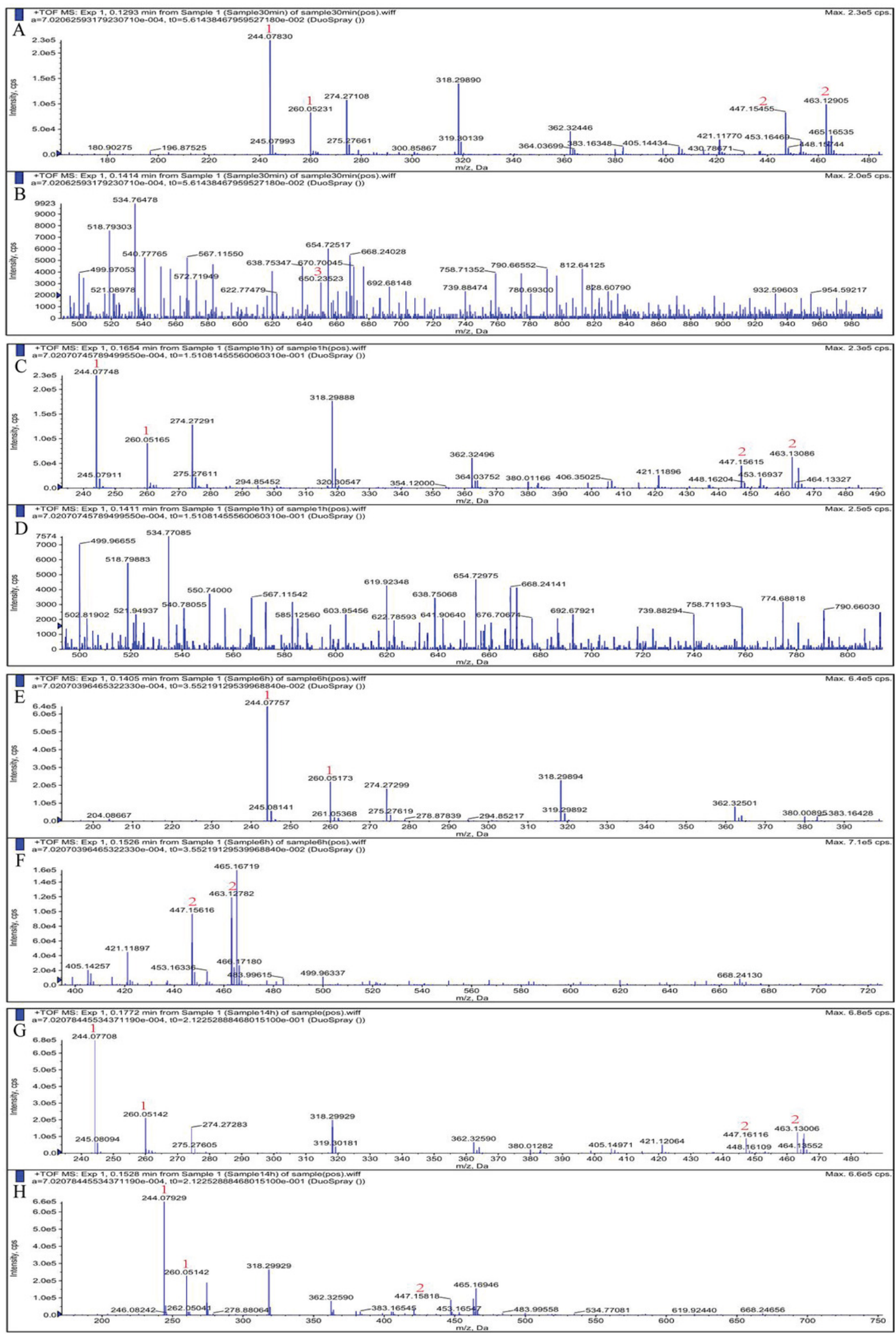